\title{
LOS AGITADORES MÓVILES: TRAYECTORIAS ANARQUISTASY VIGILANCIAS PORTUARIAS EN EL ATLÁNTICO SUDAMERICANO, 1894-1908
}

\author{
(1D) Martín Albornoz ${ }^{1 ; 2}$ \\ (1DDiego Antonio Galeano $3 ; 4$
}

\section{Resumen}

El objetivo de este artículo es estudiar la vigilancia del anarquismo en el espacio atlántico sudamericano, entre finales del siglo XIX y comienzos del siglo siguiente. Si bien la historia de la represión del anarquismo no es desconocida por la historiografía de la región, el trabajo se aleja de los abordajes clásicos, guiados por preguntas sobre su lugar en el movimiento obrero, dentro de las fronteras nacionales. A partir de la trayectoria de dos inmigrantes que circularon entre Buenos Aires, Montevideo y Río de Janeiro se busca mostrar una dinámica red de conexiones atlánticas, que abarcaba los intercambios diplomáticos, la cooperación policial y la vigilancia de los barcos que ingresaban en los puertos. En respuesta a la coyuntura, los anarquistas hicieron un uso estratégico de recursos legales (habeas corpus, peticiones a las autoridades) e ilegales (desembarcos furtivos), que no solo les permitieron sobrevivir a las embestidas represivas, sino también ampliar redes transnacionales de solidaridad libertaria.

\section{Palabras-clave}

Anarquismo - policía - vigilancia portuaria - Atlántico Sudamericano.

1 Universidad de San Martín. San Martín - Buenos Aires - Argentina.

2 Instituto de Altos Estudios Sociales. Universidad Nacional de San Martín. Consejo Nacional de Investigaciones Científicas y Técnicas (IDAES/UNSAM-CONICET, Argentina). Correo electrónico: martinalbornozc@gmail.com.

3 Pontifícia Universidade Católica. Rio de Janeiro - Rio de Janeiro - Brasil.

4 Profesor Adjunto del Departamento de Historia, en el área de Historia Contemporánea, y Director del Programa de Posgrado en Historia Social de la Cultura de la Pontificia Universidad Católica de Rio de Janeiro. E-mail: dgaleano@puc-rio.br. 


\section{THE MOBILE AGITATORS: ANARCHIST TRAJECTORIES AND THE PORT SURVEILLANCE INTHE SOUTH AMERICAN ATLANTIC, 1894-1908}

\section{(D) Martín Albornoz \\ (D) Diego Antonio Galeano}

\section{Abstract}

The goal of this article is to study the patterns of the surveillance of anarchism in the South American Atlantic space between the late nineteenth and early twentieth century. Although the history of the repression of anarchism is not unknown to the historiography of the region, our work moves away from classical approaches, guided by questions of the place of anarchism in the labor movement within national borders. Focusing on the trajectory of two immigrants who circulated between Buenos Aires, Montevideo and Rio de Janeiro, we seek to show a dynamic framework of Atlantic connections, including diplomatic exchanges, police cooperation and surveillance of ships entering the ports. In response to this situation, the anarchists strategically used legal resources (habeas corpus, petitions to the authorities) and illegal methods (disembarking in secret) which not only allowed them to survive the repressive onslaught but also expand transnational networks of activist solidarity.

\section{Keywords}

Anarchism - policing - port surveillance - South American Atlantic. 


\section{Introducción}

mediados de 1894, mientras las primeras páginas de los
diarios sudamericanos reproducían una infinidad de cró-
nicas sobre los atentados anarquistas que tenían lugar en Europa, el jefe de la policía carioca cruzaba correspondencia con el ministro de Relaciones Exteriores de Brasil. La preocupación por la "epidemia anarquista" y por la "manía homicida" que parecía encarnar, llegó a su cénit en la prensa local cuando el 25 de junio, en Lyon, el presidente francés Sadi Carnot fue asesinado de una puñalada por el anarquista Sante Caserio. Pocos días después, el canciller brasileño recibió un mensaje confidencial de la jefatura de policía. El foguista Luis Villarino - se informaba - había embarcado en el Río de la Plata, a bordo del vapor Columbia. Al realizar su escala en Río de Janeiro, el barco fue inspeccionado por la Policía Marítima para evitar el descenso de Villarino. Claramente, la misiva era una respuesta a una comunicación previa de la cancillería que abarcaba a otros casos: "en cuanto a los cuatro italianos, también anarquistas, llegados en un vapor de la Compañía Lamport \& Holt, que había salido de Buenos Aires, le recomendé al oficial de la policía del puerto que verificara a bordo". ${ }^{5}$

La carta confidencial, como las otras anteriores y las posteriores que fueron guardadas en el mismo legajo del Archivo Histórico de Itamaraty, revela que las informaciones que fueron enviadas por los cónsules (los franceses, los españoles y los italianos) eran fundamentales para la identificación de los anarquistas en tránsito. Muestra, además, la temprana inquietud de las autoridades de Brasil, Argentina y Uruguay frente a la circulación de anarquistas, que ya comenzaba a ser objeto de leyes draconianas y de decretos de emergencia

5 Archivo Histórico de Itamaraty [AHI], Policía, Oficios que fueron recibidos 300-3-5, Gabinete deJefe de Policía de Distrito Federal, carta confidencial 2 ago. 1894. 
que fueron sancionados en distintos puntos del mundo atlántico. ${ }^{6}$ En diciembre de 1893, siguiendo de cerca esas políticas represivas de gobiernos europeos, en la capital argentina empezaron a ser deportados los sujetos sospechosos de anarquismo, mezclados entre algunos ladrones y proxenetas. Las tempranas expulsiones, desde Buenos Aires, preocuparon a las policías de Montevideo, Santos y Río de Janeiro, ciudades donde los navíos hacían escala. En paralelo, junto a las misivas diplomáticas confidenciales, los diarios brasileños también mostraban a sus lectores esta ansiedad que estaba enfocada en el problema de las deportaciones de militantes y de las fragilidades de la vigilancia portuaria. ${ }^{7}$

En Argentina, por su parte, el Archivo del Ministerio de Relaciones Exteriores conserva numerosos informes que dejan entrever una misma preocupación: las autoridades policiales y las consulares temían que las rutas atlánticas sudamericanas se convirtieran en una vía de escape para los anarquistas europeos, por la facilidad de recalar en las ciudades portuarias que estaban recibiendo el aluvión inmigratorio. ${ }^{8}$ La fluidez de los intercambios diplomáticos entre ambos países, el ir y el venir de informaciones sobre la circulación de anarquistas desterrados, la elaboración de dossiers policiales, la preocupación por el escenario portuario como vía de ingreso de extranjeros indeseables y la consecuente vigilancia de vapores fueron forjando, ya desde la última década del siglo XIX, una dinámica de red de conexiones entre las ciudades atlánticas de América del Sur. El presente artículo busca indagar las distintas dimensiones de la vigilancia del

6 Sobre la legislación anti-anarquista en España, ver LÓPEZ, Ángel Herrerín. Anarquía, dinamitay revolución social. Violencia y represión en la España de entre siglos. Madrid: Catarata, 2011, p. 117-129; sobre el caso francés, ver EISENZWEIG, Uri, Fictions de l'anarchisme. Paris: Christian Bourgois, 2001. Para una perspectiva de conjunto en clave transnacional: JENSEN, Richard Bach, The Battle against anarchist terrorism. An international history. Cambridge: Cambridge University Press, 2015, p. 75-130.

7 Telegramas, Jornal do Commércio, Rio de Janeiro, 17/12/1893; Anarquistas em Buenos Aires, Correio Paulistano, São Paulo, 27/5/1894; Telegramas, O Paiz, Rio de Janeiro, 28/5/1894.

8 ALBORNOZ, Martín. Policías, cónsules y anarquistas: la dimensión transatlántica de la lucha contra el anarquismo en Buenos Aires (1889-1913). Iberoamericana, n. 64, p. 57-70, 2017. 
anarquismo, considerando, de manera conectada, las ciudades de Buenos Aires, Río de Janeiro y Montevideo. A partir de la trayectoria de dos inmigrantes que se desplazaron con frecuencia entre esos puertos, se analiza la manera en que los anarquistas lidiaron con las medidas policiales y la vigilancia portuaria.

La historiografía de la región estudió las prácticas represivas de los gobiernos argentino y brasileño, el recurso a los estados de sitio, la violencia policial en huelgas y en las manifestaciones callejeras. Pese a las diferencias específicas de cada país, la interpretación clásica y la preponderante sitúan al andamiaje legal e institucional como instrumento al servicio de las clases dominantes. De esta manera, medidas tales como la aprobación de leyes de expulsión de extranjeros en Argentina (1902) y en Brasil (1907) fueron vistas, por un lado, como las respuestas reactivas de un "estado represor" y, en algunos casos, como un punto de ruptura en las estrategias gubernamentales frente al avance del movimiento obrero y sindical en contextos locales. ${ }^{9}$ Estas interpretaciones, surgidas entre las décadas de 1970 y 1980, fueron revisadas por trabajos posteriores que, aunque ampliaron el abanico de problemas y reconocieron la existencia de elites más fragmentadas, mantuvieron la dicotomía entre la represión (estatal) y la resistencia (obrera) como matriz interpretativa. ${ }^{10}$

En este trabajo, se propone abordar la vigilancia del anarquismo y los efectos de la expulsión de extranjeros desde otro punto de vista. En primer lugar, rompe con el abordaje centrado en los casos nacionales. Otros estudios han mostrado, recientemente, la riqueza de explorar cómo las prácticas de expulsión de extranjeros, lejos de

9 Ejemplos paradigmáticos de esta perspectiva son los clásicos trabajos de MARAM, Leslie. Anarquistas, imigrantes e o movimento operário brasileiro 1890-1920. Rio de Janeiro: Paz e Terra, 1978 y SURIANO, Juan. Trabajadores, anarquismo y Estado represor: de la ley de residencia a la ley de defensa social. Buenos Aires: Centro Editor de América Latina, 1988.

10 Ver, por ejemplo, MENEZES, Lená Medeiros de. Os indesejáveis: desclassificados da modernidade. Protesto, crime expulsão na Capital Federal (1890-1930). Rio de Janeiro: Eduerj, 1996. ZIMMERMANN, Eduardo. Los liberales reformistas. La cuestión social en la argentina 1890-1916. Buenos Aires: Sudamericana/Universidad de San Andrés, 1995, p. 150-168. 
reducirse a medidas nacionalmente delimitadas, respondían a dinámicas sociales y a políticas que conectaban a los puertos atlánticos de América del Sur. ${ }^{11} \mathrm{Al}$ recuperar ese recorte geográfico y adoptar como escala de observación dos trayectorias de sujetos que fueron deportados en varias ocasiones, el artículo recupera la dimensión interactiva que se tramó entre los agentes estatales y los anarquistas. De esta forma, saliendo del enfoque prevaleciente - según el cual los libertarios habrían permanecido inertes frente a la expulsión - es posible apreciar cómo los anarquistas echaron mano a una infinidad de recursos para anular o morigerar la deportación de la que fueron objeto. A partir de la inmersión en archivos policiales, judiciales y diplomáticos, además de la prensa obrera y la comercial de Argentina, Brasil y Uruguay, se mostrará una amplia gama de respuestas articuladas por los libertarios. Lejos de una impugnación tout court de cualquier recurso a la autoridad estatal, apelaron a abogados defensores, solicitaron habeas corpus y escribieron distintas peticiones que permiten seguir sus huellas en distintos archivos.

En esta variedad de fuentes documentales también salta a la vista la centralidad de la problemática portuaria. Las expulsiones de extranjeros "indeseables" que se multiplicaron, primero con decretos de excepción y luego con leyes que fueron sancionadas por los parlamentos, incrementaron el trabajo de las policías marítimas, ya sobrecargado desde hacía tiempo por el control de insubordinaciones de marineros, conflictos a bordo de navíos mercantes y constantes reclamos de las autoridades consulares. ${ }^{12}$ Las expulsiones de los

11 SCHETTINI, Cristiana. Exploração, gênero e circuitos sul-americanos nos processos de expulsão de estrangeiros (1907-1920), Tempo, n. 33, 2012, p. 51-73; GALEANO, Diego. Criminosos viajantes: circulações transnacionais entre o Rio de Janeiro e Buenos Aires, 1890-1930, Rio de Janeiro, Arquivo Nacional, 2016. Rogerio Bonfá ha explorado desde una perspectiva comparativa las leyes de expulsión argentina y brasileña: BONFÁ, Rogerio, Com lei ou sem lei: as expulsões de estrangeiros e o conflito entre o executivo e ojudiciário na primeira república. Campinas: Universidade Estadual de Campinas, 2008.

12 NASCIMENTO, Álvaro Pereira do. A polícia e o porto: marinheiros, imigrantes e os consulados estrangeiros no Rio de Janeiro (1890-1920). In: BOHOSLAVSKY, Ernesto; CAIMARI, Lila; SCHETTINI, Cristiana (org.). La policía en perspectiva histórica: Argentina y Brasil (del siglo XIX a la actualidad). Buenos Aires: UDESA/UNGS/UNSAM, 2009. 
extranjeros que fueron acusados de robos y estafas, falsificación de moneda, proxenetismo y "delitos políticos" no hicieron más que aumentar el trabajo cotidiano de los vigilantes portuarios. En el caso del anarquismo, la intensa solidaridad internacional hizo que la puesta en práctica de las leyes de expulsión involucrara una creciente inquietud por posibles descensos en los puertos de escala y eventuales retornos clandestinos a los países que decretaban la deportación. Esa preocupación movilizó - como veremos - toda una red de intercambios diplomáticos y cooperaciones policiales que siempre terminaba con algún mandato a las autoridades portuarias: requisar la tripulación de un navío, evitar desembarcos de sospechosos y garantizar que un expulsado embarcara a su lugar de destino.

De este modo, el artículo propone cruzar dos linajes historiográficos con los desarrollos dispares en América del Sur. En primer lugar, la historia portuaria $y$, en particular, de los operarios de los puertos de Buenos Aires, Montevideo, Santos y Río de Janeiro. ${ }^{13} \mathrm{La}$ discusión sobre una cultura de solidaridad internacionalista, con fuerte presencia entre los trabajadores marítimos y los portuarios se torna aquí un elemento fundamental. Sin embargo, en lugar de privilegiar - como lo sucede en la mayor parte de la bibliografía - el vínculo entre el puerto y la ciudad, este trabajo indaga en las conexiones portuarias del espacio atlántico sudamericano. En segundo lugar, la propia historiografía del anarquismo ha mostrado una paulatina

13 La bibliografía es más vasta en Brasil y más limitada en el Río de la Plata. Ver sobre el caso de Santos: GITAHY, Maria Lucia C. Ventos do mar: trabalhadores do porto, movimento operário e cultura urbana em Santos, 1889-1914. São Paulo/Santos: Universidade Estadual Paulista, 1992 y SILVA, Fernando Teixeira da. A carga e a culpa. Os operários das docas de Santos: direitos e cultura de solidariedade, 1937-1968. São Paulo/Santos: Hucitec,1995. Sobre el puerto de Río de Janeiro ver VELASCO E CRUZ, Maria Cecília. Virando o jogo: estivadores e carregadores no Rio de Janeiro da Primeira República. Tese (Doutorado). Universidade de São Paulo, 1998. Sobre Buenos Aires ver ADELMAN, Jeremy. State and Labour in Argentina: the Portworkers of Buenos Aires, 1910-1921, Journal of Latin American Studies, vol. 25, n. 1, 1993, p. 73-102 y, más recientemente, CARUSO, Laura. Embarcados. Los trabajadores marítimos y la vida a bordo: sindicato, empresas y Estado en el puerto de Buenos aires, 1889-1921. Buenos Aires: Imago Mundi, 2016. 
tendencia a enfatizar la perspectiva transnacional..$^{14}$ En la huella de la obra de Peter Linebaugh y Marcus Rediker, Davide Turcato llamó a exhumar "la historia oculta del Atlántico anarquista". A partir de la reconstrucción minuciosa de la vida del famoso anarquista italiano Errico Malatesta, Turcato ha señalado que la historia del anarquismo atlántico no puede pensarse sin los hilos invisibles que unieron a Europa con el continente americano. ${ }^{15}$

Esa trama urdida por iniciativas comunes y contactos personales, más que mera casualidad o efecto de un inusual espíritu aventurero, explicaría la conformación de un anarquismo transatlántico que tenía a varias ciudades sudamericanas como espacios centrales. La aún incipiente bibliografía sobre el tema comienza a demostrar cómo el anarquismo y los movimientos obreros de Río de Janeiro, Buenos Aires y Montevideo fueron partícipes de un espacio común, en el cual los trabajadores portuarios construyeron sólidos vínculos de solidaridad internacional, conectando distintas ciudades de la Cuenca del Plata y Brasil. ${ }^{16}$ Esas mismas rutas fueron recorridas por los dos anarquistas cuyas trayectorias se siguen a continuación. Deportados de Brasil y Argentina en distintas ocasiones entre 1894 y 1908, las vidas

14 La historia del anarquismo transnacional ha ido creciendo de forma considerable en los últimos años. Una buena síntesis de los alcances y perspectivas que la animan puede encontrarse en BANTMAN, Constance; ALTENA, Bert (eds.). Reassessing the Transnational Turn: Scales of Analysis in Anarchist and Syndicalist Studies. Oakland: PM Press, 2017.

15 LINEBAUGH, Peter; REDIKER; Marcus. The Many-Headed Hydra: Sailors, Slaves, Commoners, and the Hidden History of the Revolutionary Atlantic. Boston: Beacon Press, 2000 y TURCATO, Davide.La historia oculta del Atlántico anarquista: Errico Malatesta en América, 1899-1900, Alcores: revista de historia contemporánea, n. 15, 2013, p. 69-87.

16 LAFORCADE, Geoffroy de. Federative Futures: Waterways, Resistance Societies, and the Subversion of Nationalism in the Early 2oth-Century Anarchism of the Río de la Plata Region, E.I.A.L., vol. 22, n. 2, 2011, p. 71-92 y OLIVEIRA, Vitor Wagner Neto de. Nás águas do Prata:trabalhadores da rota fluvial entre Buenos Aires e Corumbá (1910-1930). Campinas: Editora Unicamp, 2009, p. 223-277. De manera um poco más lateral, Eduardo Domenech analizó, a partir de la experiencia de la militante anarquista Juana Rouco Buela, cómo una expulsión originada en Buenos Aires podía derivar en Montevideo: DOMENECH"Inmigración, anarquismo y deportación. La criminalización de los extranjeros indeseables en tiempos de las grandes migraciones, REMHU, Año XXIII, n. 45, p. 169-186.-+ 
itinerantes del italiano Valentino Cordasco y del español Constante Carballo se tornan visibles en ese punto de intersección con las prácticas de expulsión de extranjeros y sus consecuencias en el mundo portuario.

\section{"Jefe de los anarquistas de América del Sur"}

El 9 de mayo de 1908, el Delegado Auxiliar de la policía de Río de Janeiro tomaba declaración testimonial por un nuevo proceso de expulsión. Casi exactamente un año atrás, el presidente de la república Afonso Pena había sancionado la ley de expulsión de extranjeros indeseables, más conocida como Ley Adolfo Gordo. Según los registros oficiales, en ese primer ciclo anual se había decretado la expulsión de más de un centenar de extranjeros, aunque muchos se quedaron en Brasil gracias a pedidos de habeas corpus. La mayoría eran acusados de reincidencia en diferentes delitos contra la propiedad, el vagabundaje, las estafas y el proxenetismo. Las listas que fueron publicadas en los informes del Ministerio de Justicia no revelan el motivo de la expulsión, pero es posible reconstruir esas acusaciones revisando los expedientes que se encuentran en el Archivo Nacional. Esa reconstrucción debe tener en cuenta las discordancias entre ambos registros: algunos nombres de las listas no constan en los legajos de expulsión y viceversa; tal era el caso del italiano que enfrentó ese día el interrogatorio del Delegado Auxiliar que no figuraba en las listas oficiales, pero el sucinto proceso de expulsión brinda algunas pistas para comprender esa ausencia. ${ }^{17}$

17 Los procesos de expulsión de extranjeros se encuentran en el Archivo Nacional de Brasil [ANB], fondo documental IJJ7, cajas 126 a 179. Las listas de los primeros decretos de expulsión están en los informes anuales del Ministerio de Justicia: Relatório apresentado ao Presidente da República dos Estados Unidos do Brasil pelo Ministro da Justiça e Negócios Interiores [RMJ]. Rio de Janeiro: Imprensa Nacional, 1907, pp. 105-106; RJM 1908, pp. 110-116 y RJM 1909, p. 93-94 
Cuando fue indagado sobre sus datos de identidad, respondió llamarse Valentino Cordasco, haber nacido en la provincia de Avellino 52 años atrás, ser soltero, sastre de oficio y ser alfabetizado. La firma que rubricaba con su nombre la declaración, pese al trazo trémulo, parece confirmar que sabía leer y escribir..$^{18} \mathrm{El} \mathrm{mismo} \mathrm{día} \mathrm{y} \mathrm{en} \mathrm{la}$ misma oficina policial, el Delegado Auxiliar escuchó a los testigos, que eran anotados como "empleados públicos", como ocurría con la mayor parte de las expulsiones de extranjeros, agentes policiales que se limitaban a corroborar la versión acusatoria de la institución. Uno de ellos, Francisco Guerra, declaró que conocía al acusado desde 1899, que era "ladrón, vagabundo, pasador de billetes falsos y que se jactaba de ser el "jefe de los anarquistas de América del Sur". La imputación mezclaba, en un mismo relato, que el italiano "recibía diarios de diversas naciones de Europa", dedicándose a la "propaganda de la anarquía", con informaciones sobre la posesión de una supuesta fortuna en Uruguay, "adquirida por medio de robos practicados en esta capital [Río de Janeiro] y en los países vecinos". ${ }^{19} \mathrm{El}$ segundo testigo repetía la misma versión, apenas agregando que Cordasco solía circular dinero falso en espacios de juego clandestino. ${ }^{20}$

Esa versión de los hechos había sido construida por la investigación policial y reafirmada por los cronistas de los diarios de circulación masiva. Conscientes de la atracción que suscitaban los anarquistas entre sus lectores desde los atentados del fin de siglo, celebraban con ironía la entrada de Río de Janeiro al concierto de ciudades que debían luchar contra este fenómeno tan moderno. En esa tónica, el caso Cordasco fue presentado a los lectores del diario O Século como uno de esos "hechos sensacionales que sugestionan al alma popular". A la capital brasileña, "civilizada" por las recientes reformas urbanas del intendente Francisco Pereira Passos, solo le faltaban "anarquistas que pusieran en desasosiego a la población". Se contaba, entonces,

18 ANB, IJJ7 140: Processo de expulsão de Valentim Cordasco (1908), Auto de qualificação do acusado. 19 Idem. Auto de declarações de Francisco Guerra.

20 Idem. Auto de declarações de Antonio da Costa Silva. 
la historia del "tenaz, intransigente y fanático Valentino Cordasco". Llegado desde el Río de la Plata el 26 de abril de 1908 a bordo del vapor Umbria, no era - se explicaba - ningún desconocido para la policía carioca. En 1900, había sido preso en Río de Janeiro por una tentativa de atentado con dinamita al entonces presidente Campos Sales, en medio de las celebraciones por el cuarto centenario del descubrimiento de Brasil. Según este relato, en su poder fue encontrada una carta sobre planes de asesinato del presidente de los Estados Unidos de América, William McKinley, que terminó muriendo en un atentado anarquista al año siguiente ${ }^{21}$.

Cuando la policía carioca supo que Cordasco pisaría de nuevo en Brasil, puso al frente de la investigación al jefe del Cuerpo de Agentes de Seguridad Pública, Arthur Andrade. Esta autoridad aseguró haber recibido de la policía uruguaya la noticia de supuestas transacciones con moneda falsa como motivo de este nuevo desplazamiento. Con la propaganda, libertaria como foco, explicaba el cronista Cordasco que había "viajado casi todo el universo" y actuaba en sus viajes como "agente de diarios anarquistas" de Buenos Aires, Nueva York y Madrid, además de dirigir un periódico libertario en Uruguay, que llevaría el título de $\mathrm{La}_{\mathrm{M}} \mathrm{Msca}^{22}$. Un día después de la primera crónica, el repórter de O Século, siempre bien comunicado con la policía, corregía la información anterior. Esta detención de mayo de 1908 no era la segunda, sino la tercera en Brasil. Seis años antes del episodio de 1900, en julio de 1894, fue detenido en la ciudad de San Pablo, en compañía de otros anarquistas italianos y fue expulsado del país. Esa detención - concluía - era el resultado de una "lista ofrecida a la policía por un cónsul italiano al que le gustaba entregarse al espionaje”. ${ }^{23}$ Presos durante la vigencia del estado de sitio que fue decretado por

21 Os anarchistas no Rio. Prisão do chefe do bando, O Século, Rio de Janeiro, 5/5/1908.

22 Idem, p. 2. Ver también: Um anarquista, O Paiz, Rio de Janeiro, 6/5/1908.

23 Os anarchistas no Rio. Prisão do chefe do bando. Valentim Cordasco, O Século, Rio de Janeiro, 6/5/1908. 
el presidente Floriano Peixoto, muchos de ellos fueron expulsados a la Argentina.

El archivo policial de Río de Janeiro brinda algunas pistas para cotejar esta versión: un informe reservado, que el ministro de Justicia envió al jefe de policía en agosto de 1894 reproduce el decreto presidencial autorizando la deportación de Cordasco. ${ }^{24}$ En la misma carpeta de este fondo documental puede encontrarse otro informe reservado, datado al comienzo de la presidencia de Prudente de Morais, en el que se solicita una lista de los extranjeros que fueron expulsados de Brasil durante la administración previa. En la respuesta, queda clara la magnitud de esa ola de expulsiones sumarias, muy anteriores a la ley de 1907: entre junio de 1893 y noviembre de 1894 se expulsaron alrededor de setenta extranjeros, la mayoría portugueses, españoles e italianos, la mitad por diversos delitos contra la propiedad y falsificaciones de dinero, mientras la otra mitad era acusada de "crímenes políticos" y anarquismo. ${ }^{25}$ En esa lista, aparece Cordasco,que fue expulsado el 18 de agosto de 1894, con destino desconocido.

Un periódico anarquista de Buenos Aires, El Perseguido, publicó una breve nota sobre el "compañero Valentín Cordasco", con la información sobre el posible itinerario: después de ser preso en San Pablo, el 29 de junio, y de pasar 52 días incomunicado, habría sido embarcado hacia Europa. ${ }^{26}$ Principal órgano de prensa libertaria de la ciudad, El Perseguido era dirigido por el anarquista español Baldomero Salvans, víctima junto a Cordasco de la represión del gobierno de Floriano Peixoto. Mientras Cordasco era detenido con un grupo de italianos en San Pablo, Salvans terminó preso en Río de Janeiro, acusado de integrar una "asociación de individuos extranjeros", la

24 ANB, GIFI/Secretaria de Polícia, 6C 5: Diretoria Geral da Justiça, Ofício Reservado n. 675, 8/8/1894. 25 Idem. Diretoria Geral dos Negócios da Justiça, Ofício Reservado n. 1, 2/1/1895.

26 Notas varias, El Perseguido, Buenos Aires, 22/11/1894. Cordasco figuraba, además, como suscriptor de este periódico: Suscripción a favor de El Perseguido, El Perseguido, Buenos Aires, 18/6/1893. 
mayoría españoles, que eran dedicados a la propaganda anarquista entre los obreros de una fábrica de tejidos del barrio de Gávea. ${ }^{27}$

En agosto de 1893, todos ellos fueron expulsados de Brasil (algunos hacia España, otros al Río de la Plata) y el cónsul español se mantuvo al tanto de los procedimientos, intercediendo entre la acción policial y su gobierno, que estaba en plena guerra contra el anarquismo por la ola de atentados de esos años. De hecho, la información no era desacertada. Uno de los más estrepitosos de estos ataques, el atentado en la Gran Vía de Barcelona, ocurriría pocos días después de estas expulsiones en Río de Janeiro, protagonizado por el tipógrafo catalán Paulino Pallás, quien regresaba a Europa tras un paso por Argentina y Brasil. Preso por la policía y ejecutado por un pelotón de fusilamiento, su nombre seguiría resonando en Europa tras el famoso atentado en el Liceo de Barcelona de noviembre de 1893, porque el anarquista que lo cometió, juró hacerlo para vengar la trágica muerte de Pallás. ${ }^{28}$ Restaban pocas dudas para los policías y los cónsules: América del Sur había entrado al denso mapa de conexiones atlánticas del anarquismo.

Al igual que Cordasco, Baldomero Salvans retornaría a Brasil años después de su primera expulsión, tras una estadía en la Argentina. Nunca saldrían de la mira policial. Es significativo notar que ambos fueron acusados de tentativas de atentado con bombas de dinamita: Cordasco de organizar un ataque al presidente brasileño y Salvans de haber lanzado bombas en una fábrica de tejidos en España. Denuncias incomprobables, pero que funcionaban para recalcar que la policía no estaba frente a simples difusores de ideas, sino ante militantes de la "propaganda por el hecho", dispuestos a matar. Esas informaciones - posiblemente inventadas por la policía - eran

27RJM 1894, p. 59. Ver también: A semana, O Paiz, Rio de Janeiro, 6/8/1893. Sobre Savans y las expulsiones de anarquistas durante la presidencia de Floriano Peixoto: LEAL, Claudia. Pensiero e Dinamite: Anarquismo e repressão em São Paulo nos anos 1890, Tese (Doutorado), Universidade Estadual de Campinas, 2006, p. 156-160.

28 FARRÉ, Juan Avilés. La daga y la dinamita: los anarquistas y el nacimiento del terrorismo. Buenos Aires: Tusquets, 2013, p. 280-295. 
fundamentales para enfrentar las resistencias que, ante las deportaciones sumarias de extranjeros, surgían del mundo jurídico y político.

Las expulsiones de extranjeros durante el gobierno de Floriano Peixoto se sustentaron en dos decretos presidenciales que le daban marco institucional a una práctica administrativa ya existente. El primero, promulgado el 13 de octubre de 1893, regulaba el ingreso de extranjeros al territorio nacional y su expulsión durante el estado de sitio. El espectro de sujetos susceptibles de deportación era amplio (mendigos, vagabundos, delincuentes de todo tipo) y se hacía énfasis en los "crímenes contra la libertad de trabajo", en los agitadores obreros que incitaran "actos de violencia contra diversas clases sociales". La expulsión se haría sin ningún proceso judicial de por medio, por una simple orden escrita del ministro de Justicia y Asuntos Interiores. Ante los cuestionamientos que fueron recibidos, un segundo decreto - revocatorio del anterior - fue publicado el 15 de diciembre del mismo año, aunque era ambiguo al refirmar la primacía de la defensa de la soberanía nacional y, de hecho, las expulsiones continuaron como atestigua el propio caso de Cordasco. Retrospectivamente, el jurista Geminiano da Franca veía en este decreto un "estado de sitio permanente" y una "dictadura hacia el extranjero", que suscitó "críticas ásperas y protestas vehementes contra esa entronización del arbitrio". ${ }^{29}$

Este abogado, que había pasado por diversos cargos en la policía carioca, incluyendo la jefatura, hasta llegar a ser juez del Supremo Tribunal Federal, era una de las tantas voces que se levantaron contra la práctica de la expulsión de extranjeros que fue empleada por los distintos gobiernos, durante el primer período republicano en Brasil. Aunque se denunciaba la inconstitucional del decreto (que pasaba por alto los derechos constitucionales de los extranjeros), el eje de la

29 Decreto $^{\circ}{ }^{1}$. 566, 13/10/1893 y Decreto $n^{\circ}$ 1.609, 15/12/1893, in Coleção de Leis do Brasil, vol. 1. Rio de Janeiro: Imprensa Nacional, 1893, p. 716-795 y FRANCA, Geminiano da. Expulsão de estrangeiros. Rio de Janeiro: Typog. Jornal do Comércio, 1930, p. 62-64. 
embestida era, según las palabras del propio Geminiano da Franca, el "poder absoluto, sin oposición", los "caprichos del ejecutivo" que avanzaban sobre los otros poderes del estado. Por eso, el redactor de la nota sobre la deportación de Cordasco en El Perseguido, de Buenos Aires, escribía que esa ola de expulsiones de extranjeros "sucedían en el Brasil, donde se abolió el imperio por una república”. Hace apenas cuatro años de la proclamación de la república en 1889, y todo esto era percibido en la región como un retroceso, como un lugar de promesas incumplidas.

La ciudad de Buenos Aires, a la que fue a parar Baldomero Salvans y, más tarde, Valentino Cordasco, no estaba al margen de estas agitaciones. Tampoco las expulsiones sumarias de anarquistas le eran desconocidas. A fines de noviembre de 1893, poco después de la expulsión de Salvans de Brasil, la prensa porteña informaba que, "en cumplimiento de severas órdenes superiores", un grupo de cuarenta anarquistas había sido detenido cuando se encontraba reunido en una cantina de la calle Callao. Según investigaciones policiales, en la reunión se tramaban huelgas entre escritores de incendiarios artículos en los periódicos ácratas. Treinta y cuatro de los detenidos fueron puestos en libertad al día siguiente, mientras el resto fue conducido al Departamento de Policía. ${ }^{30}$

Contemporáneo a los atentados anarquistas en Barcelona y $\mathrm{Pa}$ rís, el periplo de estos anarquistas convivía en los diarios porteños con el temor a esa mundializada "sed rabiosa de destrucción". Un cronista de La Prensa se acercó al Departamento de Policía cuando los anarquistas - los italianos, los españoles y los franceses - pasaron por la Oficina de Identificación, donde se le tomaron retratos y mediciones antropométricas. Al entrevistar alguno de los que fueron detenidos, el periodista los increpó sobre los atentados en Europa. Uno de ellos respondió que no ponían bombas y el otro acotó que eran, como casi todos los obreros del país, trabajadores extranjeros, que los verdaderos conspiradores eran los gobiernos. Pocos días después,

30 Batida de anarquistas, La Prensa, Buenos Aires, 5/11/1893. 
todos, a excepción de uno, que prometió no seguir profesando ideas libertarias, fueron deportados a Uruguay. ${ }^{31}$

La prensa libertaria rioplatense levantó su voz para denunciar la ola represiva. El Perseguido publicó una agria columna, con un relato sobre la creciente intolerancia de los gobiernos sudamericanos que ya se aproximaban a los peores de Europa en materia de combate al anarquismo. Sin atentados de por medio, ordenaban prisiones arbitrarias y obligaban a salir del país, bajo amenaza de ser transportados al inhóspito y gélido Cabo de Hornos. Por su parte, los periódicos ácratas de Montevideo informaron de la llegada de los deportados de Buenos Aires. Uno de ellos acusaba a la prensa comercial de ignorancia y mala fe, cuando pedía que se detuviera y encarcelara a los ocho anarquistas "que ningún delito habían cometido y fueron expulsados de Argentina debido al estado de sitio, por la sola emisión del pensamiento". ${ }^{32}$

Estos periódicos denunciaban un fenómeno que puede corroborarse con otras fuentes documentales: la emergencia de una red sudamericana de circulación de informaciones entre autoridades estatales de Argentina, Brasil y Uruguay que coordinaban acciones para vigilar a los anarquistas. De hecho, a comienzos de 1894, el jefe de la policía carioca recibió una carta del ministro de Relaciones Exteriores con una advertencia: temía que la policía de Montevideo decidiera expulsar a los ocho deportados de Buenos Aires y que en la travesía atlántica intentaran bajar en algún puerto brasileño. Dentro del mismo circuito, la policía de Buenos Aires envió a la de Río de Janeiro las fichas y las fotografías de estos desterrados, que a su vez fueron remitidas a las autoridades portuarias con el propósito de impedir su desembarco. ${ }^{33}$

31 Los anarquistas en la oficina de identificación, La Prensa, Buenos Aires, 12/12/1893 y “Deportación de anarquistas", La Prensa, Buenos Aires, 16/12/1893.

32 Persecuciones estúpidas, El Perseguido, Buenos Aires, 18/2/1894 y Annibal Ad Portas, El derecho a la vida, Montevideo, 7/1/1894.

33 ANB, GIFI/Secretaria de Polícia, 6C 5. Ministério da Justiça e Negócios Interiores, Oficio Reservado n. 46, 15/1/1894 y Oficio Reservado n. 3, 30/1/1894. 
Esta dimensión de intercambios entre autoridades policiales y consulares de distintas ciudades era fundamental. Algunos años después de su primera deportación en 1894, el italiano Valentino Cordasco reaparece en otra lista de ácratas en Brasil. Esta vez, se trataba de una "relación de los anarquistas existentes" en Río de Janeiro que el jefe de la policía envió a Olinto de Magalhães, ministro de Relaciones Exteriores entre 1898 y 1902, en sucesivas cartas con carácter confidencial. ${ }^{34}$ Mucho menos lacónica que la lista de los que fueron expulsados de 1895, en este caso se resumían los prontuarios de cada anarquista vigilado por la policía carioca. En total, sumaban cuarenta pequeñas biografías, de las cuales treinta pertenecían a italianos como Cordasco. No era una lista de extranjeros indeseables, como queda claro por la inclusión del brasileño Antonio José Duarte Junior, trabajador negro, registrado como un "socio" de Baldomero Salvans. La previa aparición de muchos de estos nombres - incluyendo al propio Salvans - en las listas de mediados de la década de 1890 sugiere líneas de continuidad en la vigilancia policial de anarquistas que circulaban por las ciudades del atlántico sudamericano. Primera en esta nueva lista de 1901, la biografía policial de Cordasco, de prosa áspera, brindaba algunas pistas sobre sus pasos posteriores a la expulsión de 1894:

Este individuo es el distribuidor del diario Protesta Humana. Vive en la calle Luis de Camões número 72. Ese diario es un órgano anarquista. Valentino se viste correctamente y usa siempre un anillo de brillante en uno de los dedos de la mano derecha. Fue deportado del estado de San Pablo en 1893, cuando era propietario de un almacén. Fue preso en esta capital el $1^{\circ}$ de mayo de 1900 . Tiene retrato en la policía de San Pablo como anarquista. No tiene aquí ningún empleo. ${ }^{35}$

34 AHI, Polícia: várias autoridades, pasta 300-3-6, Gabinete do Chefe de Polícia do Distrito Federal, cartas confidenciales al Ministro de Relaciones Exteriores de los días 8/5/1901, 11/5/1901, 20-51901, 25-5-1901, 3-6-1901 y 10-6-1901.

35 AHI, Polícia: várias autoridades, pasta 300-3-6, Gabinete do Chefe de Polícia do Distrito Federal, cartas confidenciales al Ministro de Relaciones Exteriores de los días 8/5/1901, 11/5/1901, 20-5- 
En efecto, el diario La Protesta Humana, que - según la policía carioca - Cordasco distribuía en Brasil, era uno de los órganos más importantes de la prensa anarquista rioplatense y se convertiría, pocos años más tarde, en uno de los más gravitantes del mundo atlántico. Además, desde su primer número del 13 de junio de 1897, hizo de la circulación internacional uno de sus rasgos distintivos. Inicialmente, muy cercano a la realidad europea, con el tiempo se vinculó de lleno con la problemática regional del anarquismo, alcanzando en su distribución a ciudades como Montevideo, San Pablo, Río de Janeiro, Lima, Santiago de Chile y Asunción. La dimensión transfronteriza de La Protesta Humana no se agotó en la difusión de noticias, sino que además operó como articulador de diferentes iniciativas libertarias en América del Sur. Toda una exitosa estrategia de intercambios que abarcaba cables de Montevideo y Río de Janeiro, la traducción de notas provenientes de periódicos paulistas como A Lanterna y, más adelante, La Battaglia, la publicación de correspondencias y notas de opinión hicieron de La Protesta Humana un espacio de coordinación y vinculación transnacional del propio movimiento anarquista. ${ }^{36}$

La policía carioca identificaba a Valentino Cordasco como un nodo de esa red. Cuando el jefe policial estaba terminando estas listas de ácratas para el ministro de Relaciones Exteriores decidió incluir a Cordasco una segunda vez. Sin repetir el resumen biográfico, se limitaba a agregar que, días después de la primera inclusión en la lista, el italiano había viajado a Petrópolis, regresando a Río de Janeiro poco después. Algo quedaba claro: la policía brasileña no le perdía el rastro, ni a Cordasco, ni a un centenar de anarquistas que - al igual que élcirculaban con frecuencia entre los principales puertos atlánticos de América del Sur.

1901, 25-5-1901, 3-6-1901 y 10-6-1901.

36 OVED, Iaacov. El anarquismo en el movimiento obrero en Argentina. Buenos Aires: Imago Mundi, 2013, p.79 y SURIANO, Juan. Anarquistas. Cultura y política libertaria en Buenos Aires, 1890-1910. Buenos Aires: Manantial, 2008, p. 178-214. 
Más allá de sus trayectorias singulares, todos esos casos compartían algunos rasgos. Por un lado, eran sujetos que recorrían las mismas rutas y frecuentaban las mismas redes que los trabajadores inmigrantes (la abrumadora mayoría, como revelan las listas, eran italianos y españoles). Por otro lado, enfrentaban la persecución de las autoridades de sus países de origen, que encabezaron, en la década de 1890, una severa represión internacional del anarquismo. Los efectos de esa vasta red alcanzaron a las repúblicas sudamericanas, como muestran una gran cantidad de documentos preservados en archivos policiales y diplomáticos. De hecho, en la carpeta del Itamaraty que contiene el inventario de anarquistas vigilados, otra misiva del jefe de policía al ministro de Relaciones Exteriores revela que la propia confección de las listas se debió a un pedido de autoridades de Alemania. En reunión con el canciller brasileño, los alemanes le habrían expresado la preocupación por "muchos anarquistas dirigidos al estado de Río Grande do Sul", que desde allí "se diseminaron por el territorio nacional de Brasil para luego, eludiendo la vigilancia de la policía, regresar a Europa, a fin de llevar a cabo sus planos tenebrosos" ${ }^{37}$ En efecto, todas las páginas de la lista de anarquistas que eran vigilados por la policía carioca, llevaban una anotación al margen que decía "copiado al ministro alemán".

El caso de Cordasco, se permite vislumbrar, a escala individual, el doble circuito de conexiones atlánticas, a la vez anarquista y policial. La imputación de "jefe de los anarquistas de América del Sur", formulada por el policía testigo en el proceso de expulsión de 1908, era una figuración que aludía a su papel de mediador entre periódicos libertarios de Brasil y el Río de la Plata. No es casual que muchos de los anarquistas que fueron incluidos en las listas participaran de esos emprendimientos periodísticos, que ocupaban un lugar central en las redes internacionales del anarquismo. La contracara de ese fenómeno, entonces, eran los circuitos de cooperación policial y consu-

37 AHI, Polícia: várias autoridades, pasta 300-3-6, Gabinete do Chefe de Polícia do Distrito Federal, carta confidencial 29-4-1901. 
lar, que muchas veces involucraban altas autoridades estatales en la búsqueda de contener la notable diseminación del anarquismo.

La persecución que padeció en Brasil desde los años 1890 se nutrió de esas tramas de intercambios, que envolvían a las policías de Río de Janeiro, San Pablo, Montevideo y Buenos Aires. A mediados de 1908, durante los meses de su segunda expulsión, el director de la Oficina de Identificación de la policía carioca envió una comunicación a la jefatura, informando que "según datos recibidos del servicio de investigaciones de Buenos Aires, Valentino Cordasco no registra antecedentes judiciales en aquella institución", aunque la policía porteña sabía de su existencia y lo había detenido, en febrero de 1905, cuando hacia propaganda de la resonante huelga general de ese año ${ }^{38}$. La respuesta de Buenos Aires, al negar la existencia de antecedentes delictivos y reafirmar la condición de militante anarquista, iba a contramano del argumento usado por la policía de Río de Janeiro para solicitar al gobierno su expulsión.

"Este individuo es un peligrosísimo ladrón anarquista", escribía una autoridad del Cuerpo de Agentes de Seguridad Pública que era encargada de seguirle los pasos: "dice ser vendedor de frutas, pero es solo para aparentar un medio de vida serio". ${ }^{39}$ Según esta versión, Cordasco había hecho una fortuna gracias a "transacciones ilícitas" que incluían robos, contrabando, juego clandestino, circulación de dinero falso y "propaganda del partido anarquista". Al igual que en la expulsión de 1894, estos artificios incriminatorios de la policía no pasaron sin cuestionamientos. Luego de ser preso por la policía carioca en mayo de 1908, recién llegado de Montevideo, Cordasco fue liberado mientras se tramitaba su proceso de expulsión. Entonces, se presentó en la sala de redacción del diario O Paiz, muñido de documentos de comprobaban su vida honesta y dispuesto a denunciar que

38 ANB, GIFI/Secretaria de Polícia, 6C 252. Gabinete de Identificação e Estatística, Ofício n. 4269, 1/6/1908.

39 ANB, IJJ7 140, Processo de expulsão de Valentim Cordasco (1908), Nota da Inspetoria do Corpo de Agentes de Segurança Pública do Distrito Federal, 7/5/1908. 
su persecución se debía a "informaciones falsas que fueron enviadas a la policía, por espíritu de torpe venganza”. ${ }^{\circ}$

Algunos diarios de Río de Janeiro, en franca oposición a la jefatura de policía, se hicieron eco de la denuncia. En el Correio da Manhã se leía que la prisión de Cordasco no había sido otra cosa, sino "uno de los muchos abusos que fueron practicados por inspiración de Arthur Andrade", entonces jefe del Cuerpo de Agentes de Seguridad Pública. El título de la nota - "Tempestad en un vaso de agua" - sintetizaba la diatriba periodística contra Andrade, acusado de "no tener noción alguna de lo que era un anarquista" y de haber elegido a cualquier "pobre diablo" para fraguar un éxito policial ante el supuesto "peligroso agitador de masas". Víctima del "inepto Andrade" y de su subordinado, el "zaparrastroso agente Guerra” (en alusión a Francisco Guerra, quien - como vimos - fue "testigo" en el proceso de expulsión), Cordasco había sufrido toda suerte de vejámenes y una detención de semanas en el "inmundo calabozo" del Departamento Central de Policía. En su tentativa por defenestrar a los agentes de seguridad pública y victimizar a Cordasco, sin embargo, el cronista terminaba negando no solo cualquier vínculo del italiano con el mundo del delito, sino también con el anarquismo. ${ }^{41}$

Idéntica operación repetía un periodista de la Gazeta de Notícias en una crónica titulada "Un anarquista de mentira". Cordasco - escribía - "no pasaba de un pequeño propietario que hacía viajes entre Montevideo y Río de Janeiro". A fines de 1902 se había naturalizado ciudadano de Uruguay, país en el que tenía propiedades y cuentas bancarias. Quedaba claro que Cordasco había mostrado a la prensa carioca títulos de propiedad y talonarios del banco. En vez de bombas, ironizaba el cronista, el italiano traía esos papeles en el bolsillo. $\mathrm{Al}$ igual que en los diarios O Paiz y Correio da Manhã, aquí se sugería la invención de un inexistente anarquista peligroso:

40 A polícia, O Paiz, Rio de Janeiro, 17/5/1908.

41 Tempestade em copo de água. Ainda o Valentim Cordasco, Correio da Manhã, Rio de Janeiro, $17 / 5 / 1908$. 
No hubo alma, del millón de buenas almas que habitan esta risueña ciudad, que no temblara de miedo. ¡Dios de los cielos, un anarquista! $Y$ en seguida, el nombre apareció en el noticiario como si fuera escrito con letras de fuego y de sangre: Valentino Cordasco. ${ }^{42}$

La visita a la sala de redacción de O Paiz y la versión difundida, en simultáneo, por el Correio da Manhã y la Gazeta de Notícias dejan entrever que Cordasco participó de la construcción de esta versión que lo presentaba como un cándido burgués viajero, con "paseos frecuentes” entre el Río de la Plata y Brasil, borrando así, de un plumazo, su pasado anarquista. Esa estrategia puede haber sido un consejo del abogado que presentó un habeas corpus, lo sacó del calabozo policial y, probablemente, evitó la deportación: Evaristo de Moraes. En ese momento, este personaje ya tenía una conocida actuación como defensor de derechos de militantes obreros y sindicatos, en particular de los trabajadores vinculados al mundo portuario (los estibadores, los foguistas y los cargadores de carbón). La asistencia jurídica a las asociaciones sindicales del puerto lo había convertido en un acérrimo crítico del accionar policial en un contexto marcado por fuertes movilizaciones y huelgas. ${ }^{43}$

Según consta en el proceso de expulsión, el 14 de mayo de 1908 Evaristo de Moraes presentó un habeas corpus ante un juzgado federal, pidiendo la inmediata liberación de Valentino Cordasco, en ese entonces preso en la Casa de Detención por orden de la jefatura de policía y a disposición del Ministerio de Justicia para ser expulsado de Brasil. Esa medida extraordinaria, escribía Moraes en la petición, era absurda porque no se trataba "como pretende la policía, de un

42 Um anarquista de mentira. Capitalista e... sem bombas, Gazeta de Notícias, Rio de Janeiro,17/5/1908. 43 Sobre los sindicatos portuarios y la asistencia jurídica de Evaristo de Moraes en la primera década del siglo XX ver MENDONÇA, Joseli Maria Nunes. Evaristo de Moraes, tribuno da República. Campinas: Editora da Unicamp, 2007, p. 97-128. 
anarquista o un ladrón, sin haber respondido a cualquier proceso [criminal]" ${ }^{44}$ Sería extraño que el abogado brasileño desconociera la militancia anarquista de Cordasco, pero eligió el camino de ocultarla para evitar su expulsión. En este punto, la historia de Cordasco se desvanece, sin nuevas apariciones en la documentación policial y diplomática que permitan seguir esa trayectoria repleta de desplazamientos atlánticos, algunos forzados por deportaciones y otros, la gran mayoría, por decisión propia. Tampoco parece ser objeto de nuevas crónicas en la prensa.

Detenido en San Pabloy expulsado de Brasil en 1894, algunos indicios sugieren que su destino fue un puerto europeo, pero ciertamente pasó por la Argentina a fines de esa década, antes de ser detenido en Río de Janeiro, en mayo de 1900 . Y en el camino que lo llevó a una nueva tentativa de expulsión de Brasil en 1908, la policía de Buenos Aires lo detuvo en esa ciudad al menos una vez en 1905. Si la imputación de participar en mercados ilegales (del robo, del juego clandestino y del dinero falso) puede haber sido un artificio policial para reforzar sus pedidos de expulsión, no hay dudas sobre su colaboración en el denso tejido del anarquismo sudamericano durante sus años de formación. Es probable que haya abandonado esas redes a mediados de 1908, agotado de la persecución policial o quizás continuó participando de los círculos ácratas de una manera más silenciosa.

\section{"La bestia negra de la policía"}

El 16 de diciembre de 1903, los obreros del puerto de Buenos Aires se declararon en huelga en reclamo de mejores condiciones de trabajo y reducción de la jornada laboral. Iniciada por marineros y estibadores, la medida pronto irradió a todas las actividades que com-

44 ANB, IJJ7 140, Processo de expulsão de Valentim Cordasco (1908), Pedido de habeas corpus de Evaristo de Moraes, 14/5/1908. 
ponían el heterogéneo mundo del trabajo portuario de principios del siglo XX. Obreros de los astilleros, carreros y mozos, entre otros, se sumaron a un movimiento huelguístico que, por su duración de más de dos meses y por su intensidad, fue conocido como "la huelga grande del Riachuelo". La medida, que comenzó con un reclamo contra la obligación de cargar fardos de más de cien kilos, se expandió a otras ciudades, paralizando casi por completo la actividad portuaria de la Argentina ${ }^{45}$.

Documentos de la Comisaría de Investigaciones de Buenos Aires brindan pistas sobre la vigilancia policial que acompañó de cerca a la huelga. En enero de 1904, Víctor Valle, un ex-anarquista devenido agente de investigaciones y que era conocido en el medio obrero por el pseudónimo "el manchao", redactó un informe con las impresiones que había recogido en la zona del puerto. Para Valle no era posible imaginar, en lo inmediato, el fin del movimiento huelguístico. Auguraba que, "sin temor de pecar de exagerado", podía prolongarse, como mínimo, por quince días más ${ }^{46}$. El éxito de la "huelga grande" se debía, en su opinión, a dos razones. Por un lado, al alcance geográfico de las redes de solidaridad que la sostenían y que abarcaban no solo a trabajadores de los principales puertos argentinos, sino también de Montevideo. El segundo motivo era el prestigio de los huelguistas en el barrio portuario de La Boca, en especial aquellos que formaban parte de la Sociedad de Resistencia de los Obreros del Puerto, cuya confianza los había llevado a rechazar la mediación policial para la resolución del conflicto ${ }^{47}$.

45 Sobre la "huelga grande" del puerto, ver especialmente: CARUSO, Laura. "Las hazañas del trabajo": protesta y solidaridades en la huelga grande del Riachuelo, verano de 1904. In: LOBATO, Mirta (comp.). Comunidades, historias locales y mundos del trabajo (en prensa).

46 Archivo General de la Nación Argentina [AGN], Exp. Min. Interior 1904, № 182, letra H, Informe de Víctor Valle al jefe de la División de Investigación Rossi, 11/01/1904.

47 En Argentina de principios de siglo XX, el incremento de la conflictividad laboral, un decreto del Poder Ejecutivo le asignaba a la policía el rol de mediador en los conflictos entre obreros y patrones. SURIANO, Juan. El estado argentino frente a los trabajadores urbanos. Política social y represión, 1880-1916, Anuario, n. 14, 1989-1990, p.109-136. 
Entre todos los trabajadores que participaron de la huelga (unos cinco mil según estimaciones de la época), Valle destacó la figura de Constante Carballo, alias "El Galleguito". Para el agente de investigaciones, este estibador anarquista de 28 años, nacido en La Coruña, representaba una síntesis perfecta de un novedoso tipo de activista libertario. Si durante la última década del siglo XIX el anarquista era imaginado desde la institución policial como una flor extraña, de débil implantación en suelo argentino y cuyo arribo al país se debía al agravamiento de la represión en Europa, a principios del 1900 ya se lo situaba en los intersticios del movimiento obrero local.

Desde el punto de vista de las autoridades, los dirigentes gremiales de inclinación anarquista como Carballo, a diferencia de Cordasco, buscaban ser visibles y populares en el mundo proletario. Hasta tal punto era así que el informe policial remarcaba la soltura y la seguridad con la que Carballo defendía las posiciones de los huelguistas. Refiriéndose a la decisión de rechazar el arbitraje de la policía en el conflicto del puerto, Valle apuntaba que la resolución se la comunicó el propio Carballo, "dejando vislumbrar su odio total contra toda persona que represente la autoridad, o sea contraria en sus planes y propósitos". Todo esto dicho, además, "casi en actitud de pronunciar un discurso". Valle concluía que dos soluciones podían combinarse para lograr destrabar el conflicto portuario. La primera, apostar al desgaste hasta que se resquebrajase la solidaridad imperante. La segunda, aplicar la Ley 4.114 de expulsión de extranjeros "a los cabecillas que con sus discursos sensacionales y violentos mantienen compacta a la masa obrera".$^{48}$ Conocida popularmente, con el nombre de Ley de Residencia, fue aprobada en noviembre de 1902, durante la primera huelga general en la Argentina, que también paralizó las actividades portuarias. Esta ley había nacido en un contexto de estado de sitio, bajo la sombra de la excepcionalidad y la inconstitucionalidad, reñi-

48 Informe de Víctor Valle al jefe de la División de Investigación Rossi, 11/01/1904, Op. Cit. 
da con el preámbulo de la Constitución que garantizaba derechos iguales a nativos y a extranjeros ${ }^{49}$.

La huelga finalizó con una derrota de los trabajadores y el 6 de febrero de 1904 los estibadores resolvieron levantar la medida. Sin embargo, la paralización total del puerto de Buenos Aires dejó impresionadas a las autoridades policiales. En la memoria que el Comisario de Investigaciones, José Rossi, elevó al jefe de policía, se dejaba constancia de esa impresión: "la refinada táctica empleada por una conjuración de los gremios del puerto", era sostenida por "un número dado de agitadores profesionales", algunos inmigrantes recién llegados, aunque ya se notaba la "aparición del elemento nativo". El propio Rossi puso a consideración del Ministerio del Interior - del que dependía tanto la Policía de la Capital como los decretos de expulsión de extranjeros - una lista de cuarenta y dos dirigentes gremiales para que fueran deportados por la Ley de Residencia. Tampoco en este caso la mención del nombre de Constante Carballo era azarosa. Escrita al calor del conflicto portuario, la solicitud de Rossi permite comprender algunos trazos del imaginario policial del anarquista gremial, a la vez que posibilita resituar la figura de Carballo en un contexto más amplio. Para la policía se trataba de un agitador "inteligente y astuto" que, gracias "a su verdadero prestigio", manejaba la Sociedad de Resistencia de los Obreros del Puerto "a su antojo". Era en ese gremio que el "alma y eje de todo movimiento subversivo" y tenía, además, una llamativa capacidad de confundir a la autoridad. Intuyendo que podía ser detenido, se adelantaba y pedía "amparo en las columnas de algún diario, donde tergiversando los hechos, se hace presentar como víctima de persecuciones"so.

49 Sobre los aspectos legales y sociales de la aprobación de la Ley de Residencia ver: ASPELL, Marcela. La Ley 4144 de Residencia. Antecedentes-Sanción-Aplicación, Revista del Instituto del Derecho Ricardo Levene, n. 25, 1979, p. 11-126 y OVED Iaacov. El trasfondo histórico de la ley 4.144, de Residencia, Desarrollo Económico, n. 61, 1978, p. 123-151.

50 POLICÍA DE LA CAPITAL FEDERAL. Memoria de la Comisaría de Investigaciones correspondiente al año 1904. Buenos Aires: Imprenta y encuadernación de la Policía, 1905, p. 16. 
Según Rossi, la centralidad de Carballo dentro del sindicato portuario se debía a su capacidad de articular relaciones y de lograr que otros le prestaran colaboración. En el pedido de expulsión de 1904, por ejemplo, figuran los nombres de Juan Alegre, alias "El chino alegre", uruguayo y el "anarquista convencido" que, al igual que Andrés Freire, alias "La Coruña", habrían oficiado de inspectores secretos de la Sociedad de Resistencia de los Obreros del Puerto. En el informe del jefe de policía, estos personajes eran presentados como meros "instrumentos de Carballo", dedicados a denunciar la presencia de "rompehuelgas" y proteger las medidas de fuerza de los trabajadores. Pese a la insistencia de la jefatura policial, el ministro del Interior rechazó la expulsión de Carballo y de sus compañeros, decisión que Rossi lamentó al augurar que los ácratas quedarían "gravitando sobre la industria y el trabajo" con "sus habituales consecuencias". ${ }^{51}$ Acaso la decisión del ministro se debiera al descrédito social que entonces rodeaba a la ley de expulsión de extranjeros.

La derrota de la huelga portuaria de 1903, lejos de disminuir la actividad gremial, posibilitó su proyección a escala internacional. Durante el resto del año, la experiencia de la acción conjunta de diferentes oficios y ramas del trabajo portuario fue evocada como ejemplar. Los trabajadores portuarios y, en particular, el gremio de los estibadores, cumplieron un papel central. En agosto de 1904, el periódico La Protesta anunció que comenzaría a sesionar, en la ciudad argentina de Rosario, el III Congreso Regional de Estibadores: como novedad, incluiría la presencia de trabajadores del puerto de Montevideo, en igualdad de condiciones, con sus pares de la Argentina. ${ }^{52}$ Pese a la expectativa inicial, el congreso fue un fracaso. Promediando las sesiones, varios delegados se fueron, entre ellos Constante Carballo, que había asistido como representante de los obreros del puerto de Buenos Aires. Las acusaciones cruzadas obligaron a Carballo a en-

51 AGN, Sala VII, Archivo Roca, Legajo 157: Informe del Jefe de la Policía Francisco Beazley al ministro del Interior.

52 Obreros estibadores y de ribera, La Protesta, Buenos Aires, 10/8/1904. 
viar una nota a la prensa anarquista aclarando la situación y, de este modo, afloraron desde Rosario divergencias sobre la valoración de la "huelga grande". En sus palabras "nos retiramos cuando nos convencimos de que allí no era posible hacer nada que pudiera beneficiar a la clase trabajadora" ${ }^{\prime 3}$.

La falta de acuerdo, en este congreso, de los estibadores llevó a los portuarios de Buenos Aires a lanzar una campaña por los puertos del litoral ribero con el objetivo de promover otro encuentro, esta vez en Buenos Aires. En compañía de otros estibadores, Carballo recorrió los puertos bonaerenses de Campana, Zárate, Baradero, San Pedro, San Nicolás, Villa Constitución y, finalmente, Rosario ${ }^{54}$. Desde la perspectiva libertaria, el éxito de la gira y la cercanía de los meses de mayor intensidad de trabajo en el puerto anticipaban la posibilidad de una nueva huelga portuaria en noviembre.

La intención de unir a los trabajadores portuarios de la Cuenca del Plata se entrelazó con el proyecto de hacer extensiva esa acción a Río de Janeiro. El 15 de octubre arribó a Buenos Aires una delegación de trabajadores marítimos de la capital brasileña, encabezada por el foguista Cândido João dos Santos, con el propósito de establecer un pacto de solidaridad entre los portuarios de ambas ciudades. El representante brasileño visitó, además de las diferentes asociaciones gremiales de estibadores, a carreros, a marineros y a foguistas, a la redacción del diario La Protesta. En sus oficinas, dejó constancia del clima de entusiasmo que animaba ese tipo de intercambios: "quedarán pues entabladas las relaciones de solidaridad entre las sociedades de Argentina y Brasil, entrándose en una era de cordialidades y de luchas comunes muy favorables para el movimiento proletario internacional"

53 Palestra. Más sobre el Congreso de Estibadores, La Protesta, Buenos Aires, 10/9/1904.

54 Estibadores y afines. La gira por los puertos, La Protesta, Buenos Aires, 29/9/1904.

55 Marineros y foguistas. Un delegado brasileño, La Protesta, Buenos Aires, 16/10/1904. La prensa brasileña confirma que Cândido João dos Santos era un reconocido foguista en la entonces Capital Federal de Brasil, considerado el "orador oficial” de la Sociedad Unión de los Foguistas. Ver, por ejemplo: Sociedade União dos Foguistas, Jornal do Brasil, Rio de Janeiro, 25/2/1904. 
En continuidad con la visita de Cândido João dos Santos, días más tarde representantes gremiales de los portuarios argentinos viajaron a Brasil para participar de actividades que fueron organizadas por la Sociedad Unión de los Operarios Estibadores de Río de Janeiro. Los delegados argentinos fueron el propio Constante Carballo, como secretario general de la Sociedad de Resistencia de los Estibadores de Buenos Aires, y Manuel Vázquez, secretario de la Federación Obrera Regional Argentina (FORA). En su discurso - con "voz firme y elocuencia”, según el repórter de la Gazeta de Notícias - Carballo invitó a los estibadores cariocas a seguir el ejemplo de Buenos Aires, donde la creación de gremios portuarios y la organización de huelgas también venían arrojando algunos resultados ${ }^{56}$. La "huelga grande" de la Argentina era aludida por Carballo como un ejemplo y un punto de partida para avanzar hacia un gran pacto de solidaridad entre los operarios de los puertos del Atlántico sudamericano.

Carballo llevaba a Brasil una propuesta concreta para un acuerdo basado en tres ejes principales. En primer término, las sociedades de estibadores de Río de Janeiro y Buenos Aires deberían declararse "solidarias en todos sus conflictos y luchas contra el capital". El segundo punto instaba a comunicar de inmediato a la "sociedad hermana" ante cualquier huelga o boicot contra compañías de vapores, con el fin de tomar medidas para entrelazar las luchas más allá de las fronteras nacionales. Por último, la Sociedad de Unión de los Estibadores de Río de Janeiro debía procurar, hasta donde fuera posible, "organizar en sociedades de resistencia a todos los obreros de puertos de Brasil, buscando su adhesión al presente pacto". De la misma manera, la Sociedad de Obreros del Puerto de Buenos Aires se comprometía a buscar ampliar el alcance del acuerdo a todas las sociedades de estibadores de los puertos argentinos y uruguayos ${ }^{57}$.

Este pacto fue aprobado y la Gazeta de Notícias publicó una detallada crónica de la asamblea "repleta de estibadores y miembros de va-

56 Os estivadores, Gazeta de Notícias, Rio de Janeiro, 23/10/1904.

57 Idem. 
rias facciones obreras", celebrada en el salón del Casino Comercial el día 22 de octubre. La crónica estaba acompañada por retratos de los dirigentes argentinos.

\section{Imagen I}
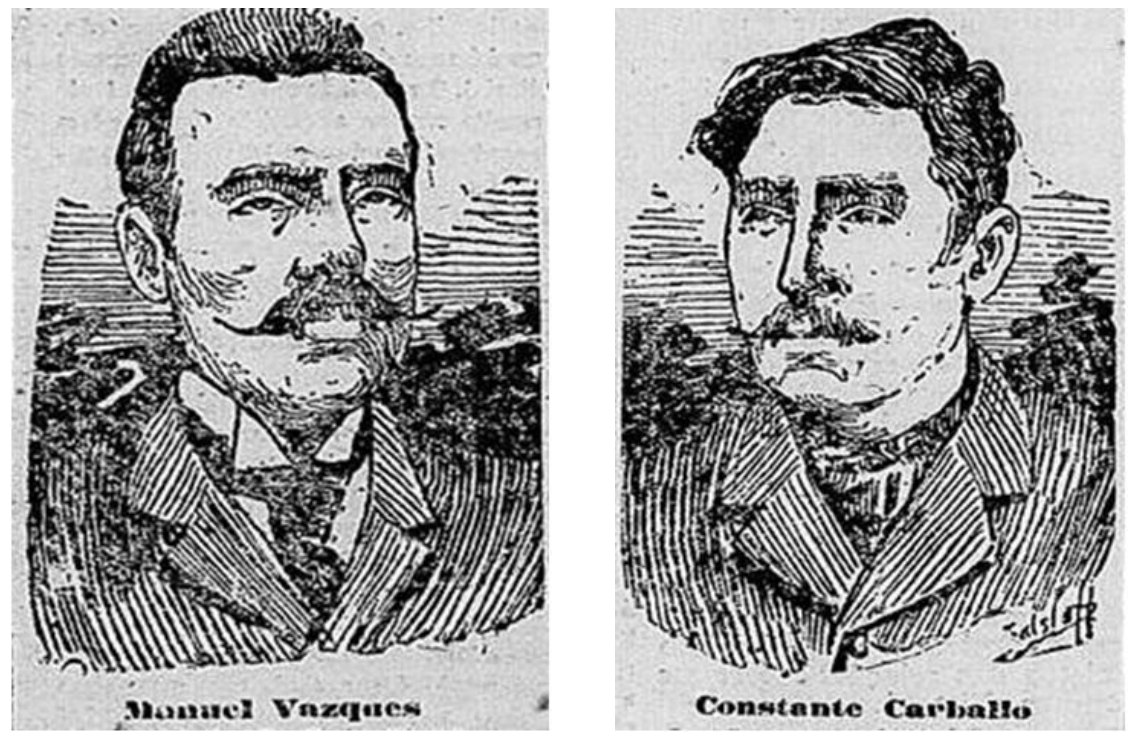

“Os estivadores", Gazeta de Notícias, Rio de Janeiro, 23/10/1904

En la mañana siguiente, Carballo y Vázquez hicieron una recorrida por la Bahía de Guanabara con el propósito de estudiar el régimen de trabajo del puerto y hablar con carboneros y otros obreros marítimos. A las tres de la tarde, los esperaba una nueva conferencia en el Casino Español. Esta vez, Vázquez fue el principal orador, en un discurso mucho más encendido, que algunos diarios cariocas 
reprodujeron. ${ }^{58}$ La enorme atención tributada a Carballo y Vázquez en Río de Janeiro fue enaltecida por los diarios libertarios de Buenos Aires. Ni bien llegaron a Río de Janeiro, fueron recogidos por un gran remolcador con "la bandera social al tope". Aun a bordo, una banda de música amenizó el paseo por la costa carioca y durante doce horas se suspendieron las labores portuarias. Luego, en andas y rodeados por una multitud, entre cantos y vivas, fueron llevados al local de los estibadores. Para los redactores de La Protesta, en un "no lejano porvenir", se vislumbraba "la victoria del trabajo sobre el capital explotador y antihumano". ${ }^{59}$

Carballo estaba dispuesto a que estos acuerdos entre estibadores de América del Sur no se convirtieran en letra muerta. Tras el regreso de la gira brasileña, en un abarrotado teatro Verdi del barrio de La Boca, inauguró el encuentro de estibadores y afines, recordando, en tono enérgico, que las luchas de los trabajadores portuarios eran recientes, pero ya bien conocidas. "Todo lo que sea combatir el capital que nos explota, todo lo que tienda a mejorar las condiciones de trabajo", proclamaba, "hallará siempre en los obreros del puerto de la capital el más desinteresado apoyo". ${ }^{60} \mathrm{~A}$ los pocos días de finalizada la reunión de trabajadores portuarios, una riña entre huelguistas y policías terminó con tres obreros muertos en la Ciudad de Rosario. Como respuesta, la FORA declaró una huelga general a comienzos de diciembre. La medida, que contó con el circunstancial apoyo de los socialistas, se sintió con fuerza en Buenos Aires, especialmente en la zona portuaria. El gobierno movilizó tropas de línea y dispuso que un crucero y el buque de guerra Maipú, de la Armada Argentina, anclaran en la rada del puerto con los cañones apuntando a la ciudad. La adhesión de los estibadores fue total y, según un cronista libertario, en

58 Os estivadores, Gazeta de Notícias, Rio de Janeiro, 24/10/1904 y Reunião operária, Jornal do Brasil,

Rio de Janeiro, 24/10/1904.

59 Estibadores, La Protesta, Buenos Aires, 25/10/1904.

60 Los obreros de los puertos, La Protesta, Buenos Aires, 12/11/1904. 
las calles del barrio de La Boca solo se observaba vacío, inmovilidad y "casas sin vida"

La situación gremial en los puertos era solo una muestra de una conflictividad que suscitó el interés y la preocupación de la policía. El mismo día que comenzaba la huelga general de diciembre de 1904, la Revista de Policía dedicó un extenso artículo a la problemática de las huelgas. A la vez que se reconocía la necesidad de actualizar la legislación vigente ante una cuestión obrera genuina, los redactores continuaban destacando la existencia de un núcleo de agitadores "de existencia conocida" que sería la explicación última de la beligerancia en el mundo del trabajo ${ }^{62}$.

El imaginario que asoció el ciclo de luchas de 1904 a la presencia de "empresarios de huelgas", como también se los conoció, obligó en ocasiones a los propios dirigentes gremiales a exacerbar su visibilidad. No tenían nada que esconder y no querían pasar por elementos extraños al medio obrero. Por esta razón, en enero de 1905, respondiendo a una denuncia del vespertino El Diario sobre la supuesta inexistencia de auténticos trabajadores en el Consejo Federal de la FORA, todos sus miembros publicaron una réplica en el órgano de la federación indicando sus lugares de trabajo. Así, Manuel Vázquez aclaraba que era cigarrero en la empresa Tres Coronas, mientras que Francisco Corney aseguraba ser tornero en un negocio de la avenida San Juan. Justamente Vázquez y Corney serían detenidos y serían expulsados junto con Carballo un mes después ${ }^{63}$. Esa política de la transparencia facilitaría, al poco tiempo, el trabajo policial.

El 4 de febrero de 1905, un grupo de civiles y militares, que eran comandados por la Unión Cívica Radical, se levantó contra el gobierno del presidente Manuel Quintana. Pese a que los anarquistas no estaban implicados en la sublevación, el gobierno decretó el estado de sitio por un mes y aprovechó la ocasión para detener a un numeroso

61 La huelga general, La Protesta, Buenos Aires, 2/12/1904.

62 Las huelgas y la policía, Revista de Policía, n. 181, Buenos Aires, 1/12/1904, p. 198.

63 Injurias graves, La Organización Obrera, Buenos Aires diciembre de 1904. 
grupo de dirigentes obreros. Cuarenta y ocho fueron alojados por casi dos semanas en el buque Maipú, hasta ser deportados a Montevideo. Entre ellos estaba Carballo. Gracias a la prensa anarquista de Montevideo (la de Buenos Aires estaba prohibida por el estado de sitio) sabemos que el 7 de febrero Carballo fue capturado cuando se encontraba solo en la zona del puerto. De manera discreta, y sin grandes despliegues de fuerza, lo detuvo un agente de la Prefectura Nacional Marítima, fuerza de seguridad creada en 1896 en reemplazo de la antigua capitanía de Puertos. Según la prensa obrera, para la policía era fundamental interceptarlo en soledad, porque si alguien presenciaba el episodio podía producirse una reacción violenta en protesta por la detención del entonces secretario de la Sociedad de Resistencia de los Obreros del Puerto ${ }^{64}$.

\section{Imagen II}

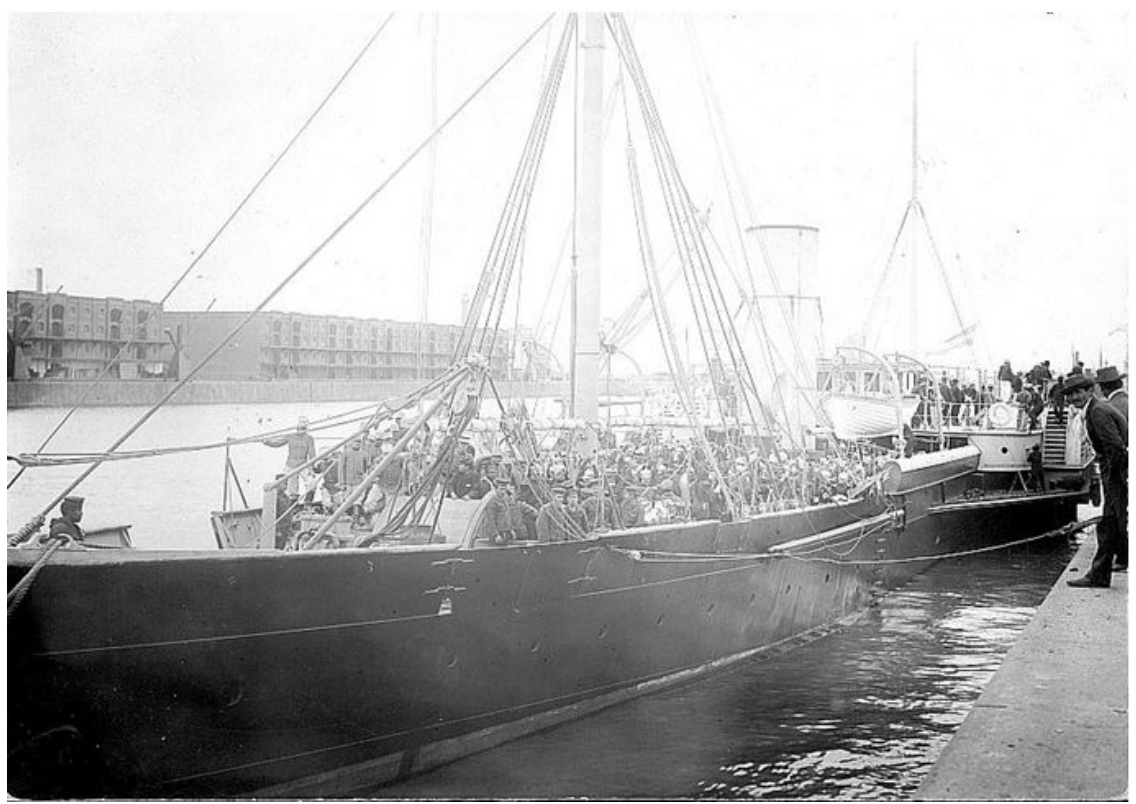

Buque de guerra Maipú transportando detenidos, 1905, Departamento

\section{Documentos Fotográficos, AGN-Argentina.}

64 El terror en la República Argentina, El Obrero, Montevideo, 21/2/1905. 
Si bien no disponemos de fuentes directas sobre la experiencia de Carballo durante su detención y deportación, es posible aproximarse a ella a través de los testimonios de varios de sus compañeros a bordo del buque Maipú. El tornero y dirigente gremial Francisco Corney dejó en un cuaderno - preservado en el archivo familiar - prolijas notas sobre esos días. El martes 7 de febrero fue detenido a las nueve de la mañana en su hogar en el barrio de La Boca. Despojado de todas sus pertenencias, fue alojado primero en un calabozo del Departamento Central de Policía y luego en el Depósito de Contraventores, donde permaneció incomunicado hasta ser trasladado al puerto de Buenos Aires, siempre custodiado por centinelas con fusiles máuser. Dentro del Maipú, anclado en la rada exterior del puerto, se encontraban los demás que habían sido expulsados, incluyendo a Carballo. Días más tarde el buque regresó al puerto y se les comunicó a los detenidos que, por decreto del poder ejecutivo, no se los dejaría retornar a la ciudad de Buenos Aires. Un vapor comercial que atravesaba el Río de la Plata, El Helios, partió la noche del sábado 18 y arribó a Montevideo con los deportados en la mañana del día siguiente. ${ }^{65}$

Otro testimonio aparece en el libro La tiranía del frac, del escritor anarquista Alberto Ghiraldo. Allí cuenta que eludió el destierro, pero llegó a estar prisionero en el Maipú, al que llamaba "cárcel flotante". Ghiraldo trazó un perfil de cada uno de los detenidos. Constante Carballo se había convertido en un "gremialista entusiasta cuya acción eficaz se ha hecho sentir, principalmente, en el seno de los estibadores" y era visto por las autoridades como "la bestia negra de la policía de La Boca, agentes marítimos y exportadores de frutos". ${ }^{66}$ Esta imagen, alusiva a su presencia descollante en el barrio portuario por excelencia de Buenos Aires, reproducía irónicamente un recurso simbólico usual entre periodistas, criminólogos y autoridades poli-

65 Francisco Corney, Cuaderno de Notas, Manuscrito del acervo familiar.

66 GHIRALDO, Alberto. La tiranía del frac. Buenos Aires: editorial La Protesta, 1905, p. 45. 
ciales: la asociación del anarquismo con representaciones, a menudo racializadas, de lo monstruoso y de lo bestial. ${ }^{67}$

Los relatos de Alberto Ghiraldo y de Francisco Corney permiten comprender el lugar de Montevideo en este espacio de conexiones atlánticas. Ya desde la aprobación de la Ley de Residencia a fines de 1902, la policía porteña observaba con preocupación cómo los anarquistas que habían sido expulsados de Buenos Aires, en vez de desembarcar en sus puertos de destino, aprovechaban la escala montevideana de la travesía para descender en el Uruguay. Esa cercanía llevó al Comisario de Investigaciones a considerar a la capital uruguaya "el cuartel general de la flor y nata del anarquismo más peligroso". La posición de cercanía territorial fue explotada por los libertarios para generar un circuito de intercambios que intentó contornar la disposición gubernamental de la expulsión. Desde la mirada policial, el permanente flujo de anarquistas era facilitado por "la inmensidad de nuestras costas", lo que tornaba "imposible la vigilancia del reingreso clandestino". ${ }^{68}$

De este modo, lejos de erradicar la propagación local del anarquismo, la Ley de Residencia contribuía a su expansión territorial, ampliando las redes de solidaridad y acción libertaria más allá de los límites nacionales. Las distintas formas que, en América del Sur, asumieron la vigilancia y la represión del anarquismo fueron también fomentadoras de un cierto internacionalismo operario. Si la tarea de propaganda llevó a Carballo a recorrer las zonas portuarias de Buenos Aires, Rosario y Río de Janeiro, su llegada a Montevideo en febrero de 1905 merece ser considerada a la luz de la circulación que la propia represión impuso al medio ácrata del novecientos. Esa misma movilidad forzada generó, a su vez, una red de cooperación policial

67 ALBORNOZ, Martín. Figuraciones del anarquismo: el anarquismo y sus representaciones culturales en Buenos Aires, 1890-1905. Tese (Doutorado). Universidad de Buenos Aires, 2015, p. 208-252.

68 POLICÍA DE LA CAPITAL FEDERAL. Memoria de la Comisaría de Investigaciones, Ob. Cit., p. 21. El refugio de anarquistas deportados de la Argentina luego de la sanción de la Ley de Residencia es analizada en un libro dedicado a la trayectoria del militante italiano Oreste Ristori: ROMANI, Carlo.Oreste Ristori: uma aventura anarquista. São Paulo: Annablume/Fapesp, 2002, p. 94-101. 
particularmente activa entre los vigilantes de Buenos Aires y sus pares del litoral atlántico brasileño. ${ }^{69}$

El lugar de Montevideo, en esta geografía de circulaciones, fue objeto de reflexión de los propios anarquistas. Mientras que la Argentina asomaba en el discurso ácrata como una versión rioplatense del terror zarista, en contraste, la otra orilla del Río de la Plata parecía un espacio de relativa libertad. En los primeros años del siglo XX, periódicos anarquistas de Buenos Aires resaltaban las diferencias entre los gobiernos argentino y uruguayo. Cuando en mayo de 1905 la policía portuaria de Montevideo evitó el descenso de dos anarquistas que habían sido expulsados de Buenos Aires a bordo del vapor Algerie, obligándolos a continuar su travesía hacia Europa; enterado de la situación, el presidente José Batlle y Ordóñez les remitió a España el dinero para retornar al Uruguay. Lo sucedido con el Algerie llevó a los redactores de La Protesta a ensayar un curioso elogio del presidente uruguayo. Al menos en contraste con su par argentino Manuel Quintana, Batlle reflejaba "la opinión de todos los hombres sensatos", que tomaban distancia de los "actos despóticos" y de la tiranía policial70. En esos días, el popular semanario ilustrado Caras y Caretas reforzaba los imaginarios de Montevideo como una especie de edén anarquista, cuando mostraba en exclusiva una fotografía de Carballo y otros deportados posando plácidamente para la cámara en un banco de la Plaza de la Independencia:

69ALBORNOZ, Martín; GALEANO Diego. Anarquistas y policías en el atlántico sudamericano: una red transnacional, 1890-1910, Boletín del Instituto de Historia Argentina y Americana "Dr. Emilio Ravignani", n. 47, 2017, p. 101-134.

70 Batlle contra Quintana, La Protesta, Buenos Aires, 22/5/1905. Ver también: Desde Montevideo, La Protesta, Buenos Aires 14/5/1905; El caso del Algerie, La Protesta, Buenos Aires,16/5/1905; y Lo del Algerie, El Libertario, Montevideo,20/5/1905. 


\section{Imagen III}

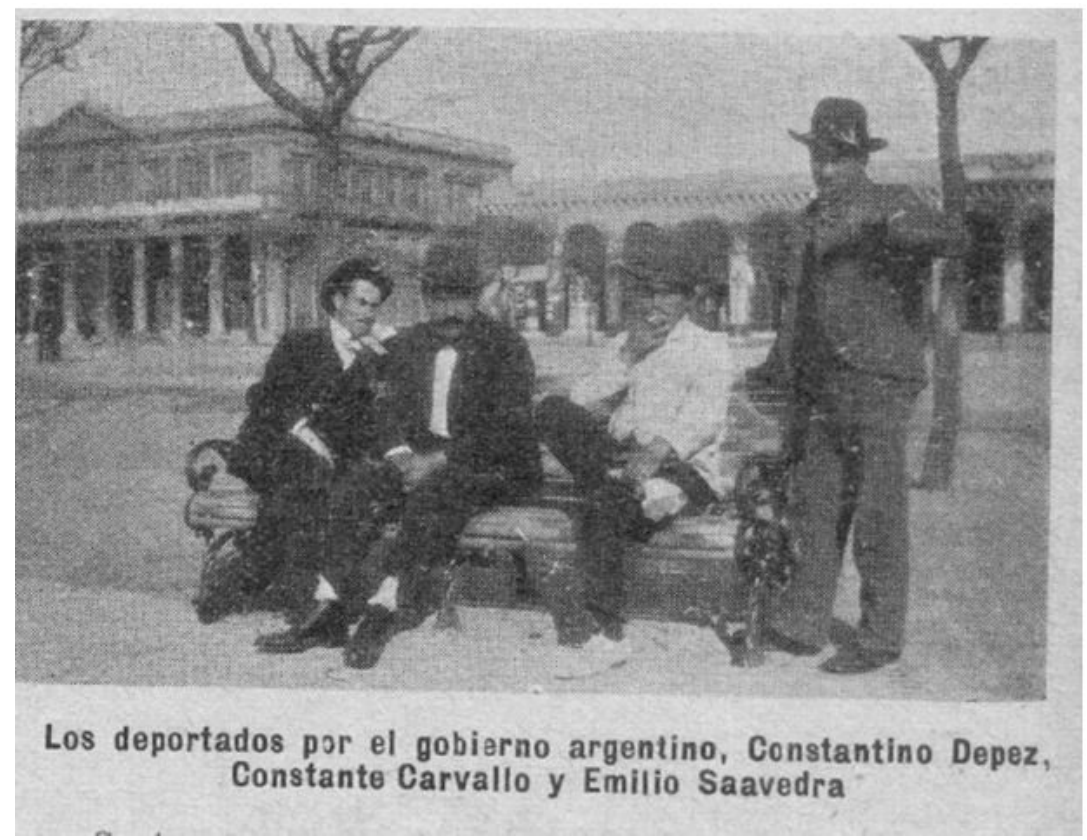

"De Montevideo. Notas de la Semana", Caras y Caretas, Nº346, 20/5/1905.

En la trayectoria de Constante Carballo se ilumina la intrincada trama de idas y vueltas suscitada por la puesta en práctica de las leyes de expulsión de extranjeros. Quien había sido uno de los militantes gremiales más visibles de los conflictos portuarios de principios de siglo, fue convirtiéndose en una figura más opaca, cuya visibilidad intermitente estuvo ligada a sus deportaciones de Buenos Aires y sus estadías en Montevideo, cada vez más prolongadas. En julio de 1905, poco después de su expulsión por la Ley de Residencia, el periódico O Século de Río de Janeiro incluyó un cable telegráfico proveniente de la Argentina: "la policía llevó a cabo la detención del peligroso anarquista Constante Carballo, que violó el destierro al que fuera conde- 
nado" ${ }^{71}$ Aunque difícil de reconstruir en su totalidad, el itinerario de expulsiones y regresos revela una situación muy distante de la imagen del desterrado de una vez y para siempre.

Expulsado de la Argentina en febrero de 1905, en julio de ese año era detenido nuevamente por la policía de Buenos Aires y, meses después, reaparece en Montevideo, lo que hace suponer que había sido deportado otra vez. Esa información consta en una carta del cónsul argentino en Uruguay. Incluida en un dossier reservado (en sí mismo un testimonio de la continuidad de la vigilancia de los anarquistas que habían sido expulsados en el lugar de destierro), la carta dejaba en claro que a comienzos de 1906 Carballo estaba viviendo en la zona portuaria de Montevideo. ${ }^{72} \mathrm{Ni}$ esa nueva deportación, ni la nueva estadía montevideana, impidieron que reapareciera en Buenos Aires en septiembre de ese año. Un suelto de La Protesta anunciaba que un grupo de deportados se encontraba de regreso en Buenos Aires en calidad de delegados al Congreso de Librepensamiento. Los libertarios sospechaban que serían, una vez más, expulsados. Y, efectivamente, el periódico anarquista montevideano La Giustizia comunicaba que, tras la inauguración del Congreso, fueron detenidos y deportados Narciso Bartolozzi y Constante Carballo. ${ }^{73}$

El juego de expulsiones y retornos clandestinos de Carballo no solo alimentó la certeza policial de que la Ley de Residencia, a la vez que procuraba cerrar la frontera contra "elementos indeseables" tendía a favorecer su circulación transfronteriza. Fue por esas idas y vueltas recurrentes que, en 1907, los redactores de La Protesta no mostraron asombro al informar que Carballo había sido detenido mientras caminaba tranquilamente por la zona portuaria de Buenos Aires y, por enésima vez, deportado. Sin dramatizar, interpretaban que el

71 Telegramas. Argentina, O Século, Rio de Janeiro, 18/7/1905.

72 Archivo Ministerio de Relaciones Exteriores de Argentina [AMRA], Legación en Uruguay, Caja AH/0045, 1901-1908, nota 13, Carta de Alejandro Guesalaga al Ministro de Relaciones Exteriores, 13 de enero de 1906.

73 Deportados argentinos, La Protesta, Buenos Aires, 20/9/1906 y Vergogne ed infamie della Reppublica Argentina, La Giustizia, Montevideo, 28/9/1906. 
gobierno argentino le estaba haciendo un favor. Un año antes, en uno de sus tantos cruces del Río de la Plata, Carballo había fijado su domicilio en la capital uruguaya. De este modo, era "una atención oficial digna de gratitud esta de pagar el viaje de regreso del compañero" ${ }^{74}$

Sin embargo, aquello que era interpretado como una rutinaria expulsión de un militante, que ya era habituado a este procedimiento policial, se convirtió en un caso de testigo de un cambio de actitud que afectó la circulación rioplatense de anarquistas. A los pocos días, la prensa montevideana anunciaba que Constante Carballo, "famoso propagandista libertario", había llegado a la ciudad a bordo del vapor Colombia y que, como resultado de las comunicaciones entre las policías de ambos países, era esperado en el puerto por dos agentes de investigaciones de Montevideo. Al llegar al muelle, los agentes le comunicaron que no podría descender por órdenes superiores y que allí se quedaría con custodia policial a la espera que el mismo vapor lo llevara de regreso a Buenos Aires. Desesperado, Carballo dio a conocer su situación a varios de sus correligionarios, con la expectativa de revocar la decisión. Pese a los esfuerzos de personalidades políticas uruguayas, como el diputado liberal Domingo Arana y el socialista Emilio Frugoni, nada pudo hacerse..$^{75} \mathrm{Al}$ día siguiente estaba de nuevo en Buenos Aires en una celda del Departamento Central de Policía. A partir de ese momento, Carballo se transformó en el "caso Carballo" y Montevideo, ciudad puerto que tan benevolente había sido en el pasado, pasó a formar parte de la geografía percibida como hostil al anarquismo, junto con Buenos Aires, San Pablo y Río de Janeiro.

El giro sorprendió a todos. Las autoridades argentinas lo celebraron, los anarquistas lo condenaron, pero tanto unos como otros dieron la misma explicación. El cambio en la política uruguaya frente a los anarquistas que habían sido expulsados de Buenos Aires se debía a la llegada al gobierno de Claudio Williman en febrero de 1907. Al igual que su antecesor Batlle y Ordóñez, Williman provenía del tradi-

74 Y van..., La Protesta, Buenos Aires, 18/7/1907.

75 El propagandista Carballo, El Siglo, Montevideo 21/7/1907. 
cional Partido Colorado, pero afrontó de forma más intransigente la cuestión de los anarquistas deportados de Buenos Aires. En una nota confidencial, el cónsul argentino en Montevideo informaba a su ministro de Relaciones Exteriores que los tiempos estaban cambiando. Había que aprovechar el momento actual y expulsar de la Argentina "a los demás agitadores de los movimientos huelguistas y a todos esos nocivos elementos". Argentina, Brasil y Uruguay no serían más territorios propicios para los ácratas, quienes, impedidos de recalar en América del Sur, tendrían, por fin, que "dirigirse a Europa desde donde no les será tan fácil regresar"776.

En esos días, Williman fue blanco predilecto de las diatribas anarquistas. En coincidencia con la percepción del cónsul argentino, un artículo incendiario que había sido publicado en Buenos Aires daba cuenta del nuevo escenario: "hasta ayer, muchos creyeron que en el Uruguay existía una relativa libertad, y ahora, deben desengañarse". El mismo escrito volcaba su furia panfletaria contra el presidente uruguayo: "un tiranuelo aristocrático", un "imbécil", "una mujerzuela de vida airada". Pese a todo, el momento no dejaba de tener su parte positiva, porque ya no habría confusas zonas grises que disimularan el enfrentamiento radical entre el "lado de la libertad" y el de la "tiranía" 7 . Mucho más sutil, Francisco Corney se mostraba optimista desde su destierro en Montevideo. No tanto frente a la posibilidad de resolver la situación de su antiguo compañero, sino en relación con el temple necesario para enfrentar el nuevo clima de época: "no nos preocupamos en lo más mínimo, porque nosotros somos los sin patria y nuestro calvario de dolores es igual en todas partes; pueden expulsarnos cuando gusten, pues, nuestro entusiasmo para propagar el grande y filosófico ideal de anarquía no va a menguar, por el contrario, crece" 78 .

76 AMRA, Sección Asuntos Políticos, año 1907, Caja 965, nota 266.

77 Frente a frente. Constante Carballo, La Protesta, Buenos Aires, 31/7/1907.

78 CORNEY, Francisco. Crónicas Montevideanas, La Protesta, Buenos Aires, 2/8/1907. 
La prensa anarquista de Montevideo y de Buenos Aires abundaba en crónicas de actos de protesta, campañas solidarias y listas de suscripción para ayudar al camarada caído en desgracia. ${ }^{79}$ Mientras tanto, en Buenos Aires, Carballo permanecía detenido. Poco afecto a la escritura, no se encuentran textos de su autoría en las páginas de periódicos y revistas libertarias. Sin embargo, una carta suya se preserva entre los miles de legajos que conforman el fondo del Ministerio del Interior. La carta, que fue enviada desde el Departamento Central de Policía al ministro Manuel Montes de Oca está fechada el 29 de julio de 1907, casi dos semanas después que la policía de Montevideo lo enviara de regreso a Buenos Aires. Carballo, el que fuera tenido por "la bestia negra de la policía de La Boca", no tomó la pluma para fustigar al orden burgués que lo mantenía cautivo, sino para "suplicar humildemente la libertad". A cambio prometía no inmiscuirse más en "ningún género de propaganda, ya sea de ideas avanzadas, o en favor de huelgas". Solo se dedicaría a trabajar para "atender honradamente" las necesidades de su familia, en especial de su madre que se hallaba muy enferma. En caso de no cumplir con su compromiso de retirarse de la vida militante, aceptaría sin discutir que se le aplicara la Ley de Residencia. En el párrafo final, Carballo se encomendaba "humildemente" y con "esperanza" a "su excelencia" el ministro del Interior a quien le deseaba, Dios mediante, muchos años de vida. ${ }^{80}$

Es difícil saber si la solicitud de Carballo se trataba de una artimaña para lograr su libertad o de un compromiso sincero. La forma en la que se han narrado las biografías anarquistas de comienzos de siglo XX no contribuyó. Lo cierto es que, desde el Ministerio del Interior, remitieron la carta de Carballo a la jefatura de policía para que se evaluara la situación. Fue el jefe Ramón Falcón quien se encargó de elaborar la respuesta rotundamente negativa. Su propio pasado lo condenaba. Al resumir los rasgos biográficos del "sujeto Constante

79 Al Pueblo, Tribuna Libertaria, Montevideo, 28/7/1907; De Montevideo, La Protesta, Buenos Aires, 31/7/1907.

80 AGN, Departamento Archivo Intermedio, Fondo del Ministerio del Interior, Legajo 16, Año 1907, N. 4211, Carta de Constante Carballo al ministro del Interior Dr. Manuel Montes de Oca, 29/7/1907. 
Carballo", Falcón recordaba que ya había sido expulsado en febrero de 1905 por "ser uno de los agitadores más eficaces y recalcitrantes de los gremios del puerto". Cinco veces había sido desterrado, cinco veces había violado su destierro. Cada vez que regresaba clandestinamente a Buenos Aires se alojaba en los barrios de La Boca y Barracas, manteniendo siempre un bajo perfil, no ejerciendo "sus actividades de agitador" para evitar ser detenido. ${ }^{81}$

Con el expediente en sus manos, el ministro del Interior decidió rechazar el pedido de Carballo y garantizar que esta vez fuera expulsado en virtud de la Ley de Residencia a su Galicia natal. No obstante, hubo lugar para un nuevo golpe de timón. Carballo no fue deportado en el vapor que debía llevarlo a España vía Inglaterra. El día 7 de agosto fue puesto en libertad. La prensa anarquista informó que la razón fue la muerte de su compañera ese mismo día. El anuncio cerraba: "lamentamos la sensible pérdida que acaba de sufrir en momentos tan angustiosos, el amigo y camarada"82, cuya huella entonces se pierde en la prensa, en los archivos policiales y diplomáticos, así como había sucedido con el italiano Valentino Cordasco.

\section{Consideraciones finales}

En mayo de 1908, mientras Evaristo de Moraes presentaba el habeas corpus de Cordasco, el diario La Protesta (que el propio anarquista italiano distribuía en Brasil), comenzó a publicar una serie de cartas del joven periodista libertario Máximo Suárez. Redactor del periódico, Suárez había sido detenido y había sido deportado desde Buenos Aires con destino a Barcelona. Como para muchos otros ácratas, su expulsión significó el comienzo de una odisea de intentos de fuga, embarques forzados, vigilancias portuarias y solidaridades militan-

81Ídem. N. 421, Carta de Ramón Falcón al ministro del Interior, 2/8/1907.

82 Constante Carballo, La Protesta, Buenos Aires, 8/8/1907. 
tes, a las que tanto la prensa comercial como obrera de la época prestaron particular atención. En una de esas misivas que Suárez dirigió a sus camaradas porteños, titulada "Viento en popa", narraba cómo al llegar al puerto de Santos en el vapor Indiana se le abalanzaron once policías paulistas al grito de "vocênão pode desembarcar", expresión que la carta, que había sido redactada en castellano, mantenía - a propósito - en portugués, reforzando la alteridad del encuentro. ${ }^{83}$

Los impedimentos de desembarco de deportados en tránsito se habían hecho rutinarios en los puertos del Atlántico sudamericano y hasta las autoridades policiales de Montevideo se sumaron, por momentos, a esta práctica de vigilancia, aunque el Uruguay careciera de una ley de expulsión de extranjeros. Inclusive dentro del espacio de militancia anarquista, el perfil de los expulsados era lo suficientemente heterogéneo para abarcar un opaco y silencioso distribuidor de La Protesta como Valentino Cordasco, un más locuaz orador y organizador de asambleas gremiales como Constante Carballo y un sesudo escritor como Máximo Suárez. Mientras el último dejó una huella más evidente en los periódicos ácratas (fuente privilegiada por los estudios históricos sobre el anarquismo), la trayectoria de los dos primeros solo puede ser reconstruida uniendo cabos sueltos en archivos policiales, diplomáticos y ministeriales.

Todos ellos, sin embargo, habitaban un mismo espacio signado por un activismo que buscó desplazarse por las ciudades sudamericanas en plan de tener redes de solidaridad. En palabras de José Aricó, gran parte del éxito del anarquismo en la región se debió a la aparición de la figura del "agitador móvil, capaz de nadar en el interior de la corriente de las luchas proletarias", una figura que "no reconocía fronteras nacionales" y se desplazaba siguiendo "una aguda intuición para percibir los signos del conflicto" ${ }^{84}$ En el mundo de los trabajadores portuarios, esos agitadores móviles fueron, especialmente, dinámicos y gravitantes. Las solidaridades tejidas entre estibadores, fo-

83Viento en Popa". Máximo Suarez desde San Pablo, La Protesta, Buenos Aires, 16/5/1908. 84 ARICÓ, José. La hipótesis de justo. Buenos Aires: Sudamericana, 1998, p. 38. 
guistas y otros operarios del puerto resultaron estratégicas a la hora de tramar desembarques y regresos furtivos a los lugares que habían tenido que abandonar por la fuerza.

En vez de estudiar la práctica de expulsión de extranjeros como una ruta que conecta el lugar de deportación con el destino final, este artículo ha buscado reponer la complejidad de la trayectoria de los desterrados, destacando el problema central de los puertos de escala. Al poner la lupa en la trama de los desembarques y de la vigilancia portuaria que buscaba impedirlos, recupera parte de la agencia histórica de los anarquistas en relación con estas medidas represivas. El punto de observación, centrado en las trayectorias de dos anarquistas que se desplazaron por distintos puertos del Atlántico sudamericano, permite vislumbrar esa ambivalente relación con los marcos legales. Cada una de las decisiones que tomaron Valentino Cordasco y Constante Carballo, en un contexto innegablemente hostil, revela estrategias colectivas de supervivencia ante las porosidades abiertas por la puesta en práctica de las expulsiones.

El análisis de los márgenes de acción de los anarquistas para operar a pesar y a través de los marcos legales exige un esfuerzo de interpretación de la geografía transatlántica en la que se movían. Por dentro de las fronteras nacionales, difícilmente se comprenda el juego de expulsiones, desembarcos y retornos, que muchas veces aprovechaban los desfasajes de la vigilancia policial y las diferencias de criterio de los gobiernos. Si los trabajadores portuarios tuvieron un lugar tan central en esta trama era porque la disputa por los efectos de los decretos y de las leyes de expulsión no terminaba cuando la policía depositaba un anarquista en el barco. Al contrario, la deportación activaba toda una trama de solidaridades y un circuito de informaciones en el cual las conexiones atlánticas de los sindicatos y militantes anarquistas desempeñaron un papel fundamental.

Las vidas de Cordasco y Carballo formaron parte de esa trama de hilos que tejieron contactos sólidos entre los puertos del Río de la Plata y del litoral brasileño. Se tornaron visibles a mediados de los años 1890 y hacia fines de la década siguiente se esfumaron. Recorrieron las mismas rutas, pasaron noches en los mismos calabozos y cami- 
naron escoltados por la policía en los mismos muelles rumbo a los vapores de las travesías de expulsión. En febrero de 1905, las secuelas de la huelga portuaria de Buenos Aires contaron con la detención de Cordasco y la expulsión de Carballo. Es muy probable que se hayan conocido, aunque los documentos que fueron consultados no permitan corroborarlo. El propagandista inquieto que atravesó la década de 1890 portando, a los ojos de la policía y de la prensa, las tan difundidas características del anarco-delincuente y el incansable militante gremial, que hacía pie en la organización obrera y la huelga, eran - a pesar de sus marcadas diferencias - parte de un mismo espacio de circulaciones, del mundo atlántico de los agitadores móviles.

\section{Bibliografia}

ADELMAN, Jeremy. State and Labour in Argentina: the Portworkers of Buenos Aires, 1910-1921, Journal of Latin American Studies, vol. 25, n. 1, 1993.

ALBORNOZ, Martín. Policías, cónsules y anarquistas: la dimensión transatlántica de la lucha contra el anarquismo en Buenos Aires (1889-1913). Iberoamericana, n. 64, p. 57-70, 2017.

ALBORNOZ, Martín. Figuraciones del anarquismo: el anarquismo y sus representaciones culturales en Buenos Aires, 1890-1905. Tese (Doutorado). Universidad de Buenos Aires, 2015.

ALBORNOZ, Martín; GALEANO Diego. Anarquistas y policías en el atlántico sudamericano: una red transnacional, 1890-1910, Boletín del Instituto de Historia Argentina y Americana "Dr. Emilio Ravignani”, n. 47, 2017, p. 101-134.

ARICÓ, José. La hipótesis de justo. Buenos Aires: Sudamericana, 1998.

ASPELL, Marcela. La Ley 4144 de Residencia. Antecedentes-Sanción-Aplicación, Revista del Instituto del Derecho Ricardo Levene, n. 25, 1979.

BANTMAN, Constance; ALTENA, Bert (eds.). Reassessing the Transnational Turn: Scales of Analysis in Anarchist and Syndicalist Studies. Oakland: PM Press, 2017.

BONFÁ, Rogerio, Com lei ou sem lei: as expulsões de estrangeiros e o conflito entre o executivo e o judiciário na primeira república. Dissertação 
(Mestrado). Universidade Estadual de Campinas, 2008.

CARUSO, Laura. "Las hazañas del trabajo": protesta y solidaridades en la huelga grande del Riachuelo, verano de 1904. In: LOBATO, Mirta (comp.). Comunidades, historias locales y mundos del trabajo (en prensa).

CARUSO, Laura. Embarcados. Los trabajadores marítimos y la vida a bordo: sindicato, empresas y Estado en el puerto de Buenos aires, 1889-1921. Buenos Aires: Imago Mundi, 2016.

DOMENECH, Eduardo Inmigración, anarquismo y deportación. La criminalización de los extranjeros indeseables en tiempos de las grandes migraciones, REMHU, n. 45, p. 169-186.

EISENZWEIG, Uri, Fictions de l'anarchisme. Paris: Christian Bourgois, 2001.

FARRÉ, Juan Avilés. La daga y la dinamita: los anarquistas y el nacimiento del terrorismo. Buenos Aires: Tusquets, 2013.

FRANCA, Geminiano da. Expulsão de estrangeiros. Rio de Janeiro: Typog. Jornal do Comércio, 1930.

GALEANO, Diego. Criminosos viajantes: circulações transnacionais entre o Rio de Janeiro e Buenos Aires, 1890-1930, Rio de Janeiro, Arquivo Nacional, 2016.

GHIRALDO, Alberto. La tiranía del frac. Buenos Aires: editorial La Protesta, 1905.

GITAHY, Maria Lucia C. Ventos do mar: trabalhadores do porto, movimento operário e cultura urbana em Santos, 1889-1914. São Paulo/Santos: Universidade Estadual Paulista, 1992.

HERRERÍN LÓPEZ, Ángel. Anarquía, dinamita y revolución social. Violencia y represión en la España de entre siglos. Madrid: Catarata, 2011.

JENSEN, Richard Bach, The Battle against anarchist terrorism. An international history. Cambridge: Cambridge University Press, 2015.

LAFORCADE, Geoffroy de. Federative Futures: Waterways, Resistance Societies, and the Subversion of Nationalism in the Early 2oth-Century Anarchism of the Río de la Plata Region, E.I.A.L., vol. 22, n. 2, 2011, p. 71-92.

LEAL, Claudia. Pensiero e Dinamite: Anarquismo e repressão em São Paulo nos anos 1890, Tese (Doutorado), Universidade Estadual de Campinas, 
2006.

LINEBAUGH, Peter; REDIKER; Marcus. The Many-Headed Hydra: Sailors, Slaves, Commoners, and the Hidden History of the Revolutionary Atlantic. Boston: Beacon Press, 2000.

MARAM, Leslie. Anarquistas, imigrantes e o movimento operário brasileiro 1890-1920. Rio de Janeiro: Paz e Terra, 1978.

MENDONÇA, Joseli Maria Nunes. Evaristo de Moraes, tribuno da República. Campinas: Editora da Unicamp, 2007.

MENEZES, Lená Medeiros de. Os indesejáveis: desclassificados da modernidade. Protesto, crime e expulsão na Capital Federal (1890-1930). Rio de Janeiro: Eduerj, 1996.

NASCIMENTO, Álvaro Pereira do. A polícia e o porto: marinheiros, imigrantes e os consulados estrangeiros no Rio de Janeiro (1890-1920). In: BOHOSLAVSKY, Ernesto; CAIMARI, Lila; SCHETTINI, Cristiana (org.). La policía en perspectiva histórica: Argentina y Brasil (del siglo XIX a la actualidad). Buenos Aires: UDESA/UNGS/UNSAM, 2009.

OLIVEIRA, Vitor Wagner Neto de. Nás águas do Prata: trabalhadores da rota fluvial entre Buenos Aires e Corumbá (1910-1930). Campinas: Editora Unicamp, 2009.

OVED Iaacov. El trasfondo histórico de la ley 4.144, de Residencia, Desarrollo Económico, n. 61, 1978, p. 123-151.

OVED, Iaacov. El anarquismo en el movimiento obrero en Argentina. Buenos Aires: Imago Mundi, 2013.

ROMANI, Carlo. Oreste Ristori: uma aventura anarquista. São Paulo: Annablume/Fapesp, 2002.

SCHETTINI, Cristiana. Exploração, gênero e circuitos sul-americanos nos processos de expulsão de estrangeiros (1907-1920), Tempo, n. 33, 2012, p. 51-73.

SILVA, Fernando Teixeira da. A carga e a culpa. Os operários das docas de Santos: direitos e cultura de solidariedade, 1937-1968. São Paulo/Santos: Hucitec,1995.

SURIANO, Juan. Anarquistas. Cultura y política libertaria en Buenos Aires, 1890-1910. Buenos Aires: Manantial, 2008.

SURIANO, Juan. El estado argentino frente a los trabajadores urbanos. Política social y represión, 1880-1916, Anuario, n. 14, 1989-1990, p.109-136. 
SURIANO, Juan. Trabajadores, anarquismo y Estado represor: de la ley de residencia a la ley de defensa social. Buenos Aires: Centro Editor de América Latina, 1988.

TURCATO, Davide. La historia oculta del Atlántico anarquista: Errico Malatesta en América, 1899-1900, Alcores: revista de historia contemporánea, n. 15, 2013, p. 69-87.

VELASCO E CRUZ, Maria Cecília. Virando o jogo: estivadores e carregadores no Rio de Janeiro da Primeira República. Tese (Doutorado). Universidade de São Paulo, 1998.

ZIMMERMANN, Eduardo. Los liberales reformistas. La cuestión social en la argentina 1890-1916. Buenos Aires: Sudamericana/Universidad de San Andrés, 1995.

Recibido en: 03/04/2018 - Aprobado en: 22/10/2018

\section{ERRATA}

Almanack n. 21

http://dx.doi.org/10.1590/2236-463320192116

No manuscrito: "Los agitadores móviles: las trayectorias anarquistas y las vigilancias portuarias en el Atlántico Sudamericano, 18941908”, com número de DOI: 10.1590/2236-463320192108, publicado no periódico Almanack, 21, na página 310/357, onde se lia:

Los agitadores móviles: las trayectorias anarquistas y las vigilancias portuarias en el Atlántico Sudamericano, 1894-1908

\section{Leia-se:}

Los agitadores móviles: trayectorias anarquistas y vigilancias portuarias en el Atlántico Sudamericano, 1894-1908 


\section{Onde se lia:}

The mobile agitators: the anarchist trajectories and the port surveillance in the South American Atlantic, 1894-1908

\section{Leia-se:}

The mobile agitators: anarchist trajectories and port surveillance in the south american atlantic, 1894-1908

Na página 310/357, na seção Resumen, onde se lia:

[...]comienzos del siglo siguiente [...]

\section{Leia-se:}

[...]comienzos del siguiente [...]

\section{E onde se lia:}

A partir de la trayectoria de dos inmigrantes que circularon entre Buenos Aires, Montevideo y Río de Janeiro se busca mostrar una dinámica red de conexiones atlánticas, que abarcaba los intercambios diplomáticos, la cooperación policial y la vigilancia de los barcos que ingresaban en los puertos. En respuesta a la coyuntura, los anarquistas hicieron un uso estratégico de recursos legales (habeas corpus, peticiones a las autoridades) e ilegales (desembarcos furtivos), que no solo les permitieron sobrevivir a las embestidas represivas, sino también ampliar redes transnacionales de solidaridad libertaria.

\section{Leia-se:}

A partir de la trayectoria de dos inmigrantes que circularon entre Buenos Aires, Montevideo y Río de Janeiro se busca mostrar una dinámica red de conexiones atlánticas que abarcaba intercambios diplomáticos, cooperación policial y vigilancia de los barcos que ingresaban en los puertos. En respuesta a la coyuntura, los anarquistas hicieron un uso estratégico de recursos legales (habeas corpus, 
peticiones a las autoridades) e ilegales (desembarcos furtivos) que no solo les permitieron sobrevivir a las embestidas represivas sino también ampliar redes transnacionales de solidaridad libertaria.

Na página 312/357, na seção Introdución, onde se lia:

La preocupación por la "epidemia anarquista" y por la "manía homicida" que parecía encarnar, llegó a su cénit en la prensa local cuando el 25 de junio, en Lyon, el presidente francés Sadi Carnot fue asesinado de una puñalada por el anarquista Sante Caserio. Pocos días después, el canciller brasileño recibió un mensaje confidencial de la jefatura de policía. El foguista Luis Villarino - se informaba había embarcado en el Río de la Plata, a bordo del vapor Columbia. Al realizar su escala en Río de Janeiro, el barco fue inspeccionado por la Policía Marítima para evitar el descenso de Villarino. Claramente, la misiva era una respuesta a una comunicación previa de la cancillería que abarcaba a otros casos: "en cuanto a los cuatro italianos, también anarquistas, llegados en un vapor de la Compañía Lamport \& Holt, que había salido de Buenos Aires, le recomendé al oficial de la policía del puerto que verificara a bordo".

\section{Leia-se:}

La preocupación por la "epidemia anarquista" y por la "manía homicida" que parecía encarnar llegó a su cénit en la prensa local cuando el 25 de junio, en Lyon, el presidente francés Sadi Carnot fue asesinado de una puñalada por el anarquista Sante Caserio. Pocos días después, el canciller brasileño recibió un mensaje confidencial de la jefatura de policía. El foguista Luis Villarino - se informaba había embarcado en el Río de la Plata, a bordo del vapor Columbia. Al realizar su escala en Río de Janeiro, el barco fue inspeccionado por la Policía Marítima para evitar el descenso de Villarino. Claramente la misiva era una respuesta a una comunicación previa de la cancillería que abarcaba otros casos: "en cuanto a los cuatro italianos, también anarquistas, llegados en un vapor de la Compañía Lamport \& Holt, salido de Buenos Aires, recomendé al oficial de la policía del puerto que verificara a bordo". 


\section{Nas páginas 312-314/357, onde se lia:}

La carta confidencial, como las otras anteriores y las posteriores que fueron guardadas en el mismo legajo del Archivo Histórico de Itamaraty, revela que las informaciones que fueron enviadas por los cónsules (los franceses, los españoles y los italianos) eran fundamentales para la identificación de los anarquistas en tránsito. Muestra, además, la temprana inquietud de las autoridades de Brasil, Argentina y Uruguay frente a la circulación de anarquistas, que ya comenzaban a ser objeto de leyes draconianas y de decretos de emergencia que fueron sancionados en distintos puntos del mundo atlántico. En diciembre de 1893, siguiendo de cerca esas políticas represivas de gobiernos europeos, en la capital argentina empezaron a ser deportados los sujetos sospechosos de anarquismo, mezclados entre algunos ladrones y proxenetas. Las tempranas expulsiones, desde Buenos Aires, preocuparon a las policías de Montevideo, Santos y Río de Janeiro, ciudades donde los navíos hacían escala. En paralelo, junto a las misivas diplomáticas confidenciales, los diarios brasileños también mostraban a sus lectores esta ansiedad que estaba enfocada en el problema de las deportaciones de militantes y de las fragilidades de la vigilancia portuaria.

En la Argentina, por su parte, el Archivo del Ministerio de Relaciones Exteriores conserva numerosos informes que dejan entrever una misma preocupación: las autoridades policiales y las consulares temían que las rutas atlánticas sudamericanas se convirtieran en una vía de escape para los anarquistas europeos, por la facilidad de recalar en las ciudades portuarias que estaban recibiendo el aluvión inmigratorio. La fluidez de los intercambios diplomáticos entre ambos países, el ir y el venir de informaciones sobre la circulación de anarquistas desterrados, la elaboración de dossiers policiales, la preocupación por el escenario portuario como vía de ingreso de extranjeros indeseables y la consecuente vigilancia de vapores, fueron forjando, ya desde la última década del siglo XIX, una dinámica de red de conexiones entre las ciudades atlánticas de América del Sur. El presente artículo busca indagar las distintas dimensiones de la vigilancia del anarquismo, considerando, de manera conectada, las 
ciudades de Buenos Aires, Río de Janeiro y Montevideo. A partir de la trayectoria de dos inmigrantes que se desplazaron con frecuencia entre esos puertos, analiza la manera en que los anarquistas lidiaron con las medidas policiales y la vigilancia portuaria.

La historiografía de la región estudió las prácticas represivas de los gobiernos argentino y brasileño, el recurso a los estados de sitio, la violencia policial en huelgas y en las manifestaciones callejeras. Pese a las diferencias específicas de cada país, la interpretación clásica y la preponderante sitúan al andamiaje legal e al institucional como instrumento al servicio de las clases dominantes. De esta manera, medidas tales como la aprobación de leyes de expulsión de extranjeros en Argentina (1902) y en Brasil (1907) fueron vistas, por un lado, como las respuestas reactivas de un "estado represor" y, en algunos casos, como un punto de ruptura en las estrategias gubernamentales frente al avance del movimiento obrero y sindical en contextos locales. Estas interpretaciones, surgidas entre las décadas de 1970 y 1980, fueron revisadas por trabajos posteriores que, aunque ampliaron el abanico de problemas y reconocieron la existencia de elites más fragmentadas, mantuvieron la dicotomía entre la represión (estatal) y la resistencia (obrera) como matriz interpretativa.

\section{Leia-se:}

La carta confidencial, como otras anteriores y posteriores guardadas en el mismo legajo del Archivo Histórico Itamaraty, revela que las informaciones enviadas por los cónsules (franceses, españoles e italianos) eran fundamentales para la identificación de anarquistas en tránsito. Muestra, además, la temprana inquietud de las autoridades de Brasil, Argentina y Uruguay frente a circulación de anarquistas, que ya comenzaban a ser objeto de leyes draconianas y decretos de emergencia sancionados en distintos puntos del mundo atlántico. En diciembre de 1893, siguiendo de cerca esas políticas represivas de gobiernos europeos, en la capital argentina empezaron a ser deportados sujetos sospechosos de anarquismo, mezclados entre algunos ladrones y proxenetas. Las tempranas expulsiones desde Buenos Aires preocuparon a las policías de Montevideo, Santos y Río de Janeiro, ciudades donde los navíos hacían escala. En 
paralelo, junto a las misivas diplomáticas confidenciales, los diarios brasileños también mostraban a sus lectores esta ansiedad enfocada en el problema de las deportaciones de militantes y las fragilidades de la vigilancia portuaria.

En la Argentina, por su parte, el Archivo del Ministerio de Relaciones Exteriores conserva numerosos informes que dejan entrever una misma preocupación: las autoridades policiales y consulares temían que las rutas atlánticas sudamericanas se convirtieran en una vía de escape para los anarquistas europeos, por la facilidad de recalar en las ciudades portuarias que estaban recibiendo el aluvión inmigratorio. La fluidez de los intercambios diplomáticos entre ambos países, el ir y venir de informaciones sobre la circulación de anarquistas desterrados, la elaboración de dossiers policiales, la preocupación por el escenario portuario como vía de ingreso de extranjeros indeseables y la consecuente vigilancia de vapores, fueron forjando, ya desde la última década del siglo XIX, una dinámica red de conexiones entre las ciudades atlánticas de América del Sur. El presente artículo busca indagar las distintas dimensiones de la vigilancia del anarquismo considerando de manera conectada las ciudades de Buenos Aires, Río de Janeiro y Montevideo. A partir de la trayectoria de dos inmigrantes que se desplazaron con frecuencia entre esos puertos, analiza la manera en que los anarquistas lidiaron con las medidas policiales y la vigilancia portuaria.

La historiografía de la región estudió las prácticas represivas de los gobiernos argentino y brasileño, el recurso a los estados de sitio, la violencia policial en huelgas y en manifestaciones callejeras. Pese a las diferencias específicas de cada país, la interpretación clásica y preponderante sitúa al andamiaje legal e institucional como instrumento al servicio de las clases dominantes. De esta manera, medidas tales como la aprobación de leyes de expulsión de extranjeros en Argentina (1902) y en Brasil (1907) fueron vistas, por un lado, como respuestas reactivas de un "estado represor" y, en algunos casos, como un punto de ruptura en las estrategias gubernamentales frente al avance del movimiento obrero y sindical en contextos locales. Estas interpretaciones, surgidas entre las décadas de 1970 y 1980, 
fueron revisadas por trabajos posteriores que, aunque ampliaron el abanico de problemas y reconocieron la existencia de elites más fragmentadas, mantuvieron la dicotomía entre represión (estatal) y resistencia (obrera) como matriz interpretativa.

\section{Na página 314/357, onde se lia:}

En este trabajo, se propone abordar la vigilancia del anarquismo y los efectos de la expulsión de extranjeros desde otro punto de vista. En primer lugar, rompe con el abordaje centrado en los casos nacionales. Otros estudios han mostrado, recientemente, la riqueza de explorar cómo las prácticas de expulsión de extranjeros, lejos de reducirse a medidas nacionalmente delimitadas, respondían a dinámicas sociales y a políticas que conectaban a los puertos atlánticos de América del Sur. Al recuperar ese recorte geográfico y adoptar como escala de observación dos trayectorias de sujetos que fueron deportados en varias ocasiones, el artículo recupera la dimensión interactiva que se tramó entre los agentes estatales y los anarquistas. De esta forma, saliendo del enfoque prevaleciente - según el cual los libertarios habrían permanecido inertes frente a la expulsión-es posible apreciar cómo los anarquistas echaron mano a una infinidad de recursos para anular o morigerar la deportación de la que fueron objeto. A partir de la inmersión en archivos policiales, judiciales y diplomáticos, además de la prensa obrera y la comercial de Argentina, Brasil y Uruguay, se mostrará una amplia gama de respuestas articuladas por los libertarios. Lejos de una impugnación tout court de cualquier recurso a la autoridad estatal, apelaron a abogados defensores, solicitaron habeas corpus y escribieron distintas peticiones que permiten seguir sus huellas en distintos archivos.

\section{Leia-se:}

Este trabajo se propone abordar la vigilancia del anarquismo y los efectos de la expulsión de extranjeros desde otro punto de vista. En primer lugar, rompe con el abordaje centrado en los casos nacionales. Otros estudios han mostrado, recientemente, la riqueza 
de explorar cómo las prácticas de expulsión de extranjeros, lejos de reducirse a medidas nacionalmente delimitadas, respondían a dinámicas sociales y políticas que conectaban a los puertos atlánticos de América del Sur. Al recuperar ese recorte geográfico y adoptar como escala de observación dos trayectorias de sujetos deportados en varias ocasiones, el artículo recupera la dimensión interactiva que se tramó entre agentes estatales y anarquistas. De esta forma, saliendo del enfoque prevaleciente - según el cual los libertarios habrían permanecido inertes frente a la expulsión - es posible apreciar cómo los anarquistas echaron mano a una infinidad de recursos para anular o morigerar la deportación de la que fueron objeto. A partir de la inmersión en archivos policiales, judiciales y diplomáticos, además de prensa obrera y comercial de Argentina, Brasil y Uruguay, se mostrará una amplia gama de respuestas articuladas por los libertarios. Lejos de una impugnación tout court de cualquier recurso a la autoridad estatal, apelaron a abogados defensores, solicitaron habeas corpus y escribieron distintas peticiones que permiten seguir sus huellas en distintos archivos.

\section{Nas páginas 315-316/357, onde se lia:}

En esta variedad de fuentes documentales también salta a la vista la centralidad de la problemática portuaria. Las expulsiones de extranjeros "indeseables" que se multiplicaron, primero con decretos de excepción y luego con leyes que fueron sancionadas por los parlamentos, incrementaron el trabajo de las policías marítimas, ya sobrecargado desde hacía tiempo por el control de insubordinaciones de marineros, conflictos a bordo de navíos mercantes y constantes reclamos de las autoridades consulares. Las expulsiones de los extranjeros que fueron acusados de robos y estafas, falsificación de moneda, proxenetismo y "delitos políticos" no hicieron más que aumentar el trabajo cotidiano de los vigilantes portuarios. En el caso del anarquismo, la intensa solidaridad internacional hizo que la puesta en práctica de las leyes de expulsión involucrara una creciente inquietud por posibles descensos en los puertos de escala y eventuales retornos clandestinos a los países que decretaban la deportación. Esa preocupación movilizó-comoveremos-toda una red de intercambios diplomáticos y cooperaciones policiales que siempre terminaba con 
algún mandato a las autoridades portuarias: requisar la tripulación de un navío, evitar desembarcos de sospechosos y garantizar que un expulsado embarcara a su lugar de destino.

De este modo, el artículo propone cruzar dos linajes historiográficos con los desarrollos dispares en América del Sur. En primer lugar, la historia portuaria y, en particular, de los operarios de los puertos de Buenos Aires, Montevideo, Santos y Río de Janeiro. La discusión sobre una cultura de solidaridad internacionalista, con fuerte presencia entre los trabajadores marítimos y los portuarios se torna aquí un elemento fundamental. Sin embargo, en lugar de privilegiar - como lo sucede en la mayor parte de la bibliografía - el vínculo entre el puerto y la ciudad, este trabajo indaga en las conexiones portuarias del espacio atlántico sudamericano.

\section{Leia-se:}

En esta variedad de fuentes documentales también salta a la vista la centralidad de la problemática portuaria. Las expulsiones de extranjeros "indeseables" que se multiplicaron, primero con decretos de excepción y luego con leyes sancionadas por los parlamentos, incrementaron el trabajo de las policías marítimas, ya sobrecargado desde hacía tiempo por el control de insubordinaciones de marineros, conflictos a bordo de navíos mercantes y constantes reclamos de las autoridades consulares. Las expulsiones de extranjeros acusados de robos y estafas, falsificación de moneda, proxenetismo y "delitos políticos" no hicieron más que aumentar el trabajo cotidiano de los vigilantes portuarios. En el caso del anarquismo, la intensa solidaridad internacional hizo que la puesta en práctica de las leyes de expulsión involucrara una creciente inquietud por posibles descensos en los puertos de escala y eventuales retornos clandestinos a los países que decretaban la deportación. Esa preocupación movilizó - como veremos - toda una red de intercambios diplomáticos y cooperaciones policiales que siempre terminaba con algún mandato a las autoridades portuarias: requisar la tripulación de un navío, evitar desembarcos de sospechosos y garantizar que un expulsado embarcara a su lugar de destino. 
De este modo, el artículo propone cruzar dos linajes historiográficos con desarrollos dispares en América del Sur. En primer lugar, la historia portuaria y, en particular, de los operarios de los puertos de Buenos Aires, Montevideo, Santos y Río de Janeiro. La discusión sobre una cultura de solidaridad internacionalista con fuerte presencia entre los trabajadores marítimos y portuarios se torna aquí un elemento fundamental. Sin embargo, en lugar de privilegiar - como sucede en la mayor parte de la bibliografía - el vínculo entre puerto y ciudad, este trabajo indaga en las conexiones portuarias del espacio atlántico sudamericano.

Nas páginas 318-332/357, na seção "Jefe de los anarquistas de América del Sur", onde se lia:

El9 de mayo de 1908, el Delegado Auxiliar de la policía de Río de Janeiro tomaba declaración testimonial por un nuevo proceso de expulsión. Casi exactamente un año atrás, el presidente de la república Afonso Pena había sancionado la ley de expulsión de extranjeros indeseables, más conocida como Ley Adolfo Gordo. Según los registros oficiales, en ese primer ciclo anual se había decretado la expulsión de más de un centenar de extranjeros, aunque muchos se quedaron en Brasil gracias a pedidos de habeas corpus. La mayoría eran acusados de reincidencia en diferentes delitos contra la propiedad, el vagabundaje, las estafas y el proxenetismo. Las listas que fueron publicadas en los informes del Ministerio de Justicia no revelan el motivo de la expulsión, pero es posible reconstruir esas acusaciones revisando los expedientes que se encuentran en el Archivo Nacional. Esa reconstrucción debe tener en cuenta las discordancias entre ambos registros: algunos nombres de las listas no constan en los legajos de expulsión y viceversa; $t$. Tal era el caso del italiano que enfrentó ese día el interrogatorio del Delegado Auxiliar que n. No figuraba en las listas oficiales, pero el sucinto proceso de expulsión brinda algunas pistas para comprender esa ausencia.

Cuando fue indagado sobre sus datos de identidad, respondió llamarse Valentino Cordasco, haber nacido en la provincia de 
Avellino 52 años atrás, ser soltero, sastre de oficio y ser alfabetizado. La firma que rubricaba con su nombre la declaración, pese al trazo trémulo, parece confirmar que sabía leer y escribir. El mismo día y en la misma oficina policial, el Delegado Auxiliar escuchó a los testigos, que eran a. Anotados como "empleados públicos” eran, como ocurría con la mayor parte de las expulsiones de extranjeros, agentes policiales que se limitaban a corroborar la versión acusatoria de la institución. Uno de ellos, Francisco Guerra, declaró que conocía al acusado desde 1899, que era "ladrón, vagabundo, pasador de billetes falsos y que se jactaba de ser el "jefe de los anarquistas de América del Sur". La imputación mezclaba, en un mismo relato, que el italiano "recibía diarios de diversas naciones de Europa", dedicándose a la "propaganda de la anarquía", con informaciones sobre la posesión de una supuesta fortuna en Uruguay, "adquirida por medio de robos practicados en esta capital [Río de Janeiro] y en los países vecinos”. El segundo testigo repetía la misma versión, apenas agregando que Cordasco solía circular dinero falso en espacios de juego clandestino.

Esa versión de los hechos había sido construida por la investigación policial y reafirmada por los cronistas de los diarios de circulación masiva. Conscientes de la atracción que suscitaban los anarquistas entre sus lectores desde los atentados del fin de siglo, celebraban con ironía la entrada de Río de Janeiro al concierto de ciudades que debían luchar contra este fenómeno tan moderno. En esa tónica, el caso Cordasco fue presentado a los lectores del diario O Século como uno de esos "hechos sensacionales que sugestionan al alma popular". A la capital brasileña, "civilizada" por las recientes reformas urbanas del intendente Francisco Pereira Passos, solo le faltaban "anarquistas que pusieran en desasosiego a la población”. Se contaba, entonces, la historia del "tenaz, intransigente y fanático Valentino Cordasco". Llegado desde el Río de la Plata el 26 de abril de 1908 a bordo del vapor Umbria, no era - se explicaba - ningún desconocido para la policía carioca. En 1900, había sido preso en Río de Janeiro por una tentativa de atentado con dinamita al entonces presidente Campos Sales, en medio de las celebraciones por el cuarto centenario del descubrimiento de Brasil. Según este relato, en su poder fue encontrada una carta sobre planes de asesinato del presidente de los Estados Unidos de 
América, William McKinley, que terminó muriendo en un atentado anarquista al año siguiente.

Cuando la policía carioca supo que Cordasco pisaría de nuevo en Brasil, puso al frente de la investigación al jefe del Cuerpo de Agentes de Seguridad Pública, Arthur Andrade. Esta autoridad aseguró haber recibido de la policía uruguaya la noticia de supuestas transacciones con moneda falsa como motivo de este nuevo desplazamiento. Con la propaganda, libertaria como foco, explicaba el cronista, Cordasco que había "viajado casi todo el universo" y actuaba en sus viajes como "agente de diarios anarquistas" de Buenos Aires, Nueva York y Madrid, además de dirigir un periódico libertario en el Uruguay, que llevaría el título de La Mosca. Un día después de la primera crónica, el repórter de O Século, siempre bien comunicado con la policía, corregía la información anterior. Esta detención de mayo de 1908 no era la segunda, sino la tercera en Brasil. Seis años antes del episodio de 1900, en julio de 1894, fue detenido en la ciudad de San Pablo, en compañía de otros anarquistas italianos y fue expulsado del país. Esa detención - concluía - era el resultado de una "lista ofrecida a la policía por un cónsul italiano al que le gustaba entregarse al espionaje". Presos durante la vigencia del estado de sitio que fue decretado por el presidente Floriano Peixoto, muchos de ellos fueron expulsados a la Argentina.

El archivo policial de Río de Janeiro brinda algunas pistas para cotejar esta versión: un informe reservado, que el ministro de Justicia envió al jefe de policía en agosto de 1894 reproduce el decreto presidencial autorizando la deportación de Cordasco. En la misma carpeta de este fondo documental puede encontrarse otro informe reservado, datado al comienzo de la presidencia de Prudente de Morais, en el que se solicita una lista de los extranjeros que fueron expulsados de Brasil durante la administración previa. En la respuesta, queda clara la magnitud de esa ola de expulsiones sumarias, muy anteriores a la ley de 1907: entre junio de 1893 y noviembre de 1894 se expulsaron alrededor de setenta extranjeros, la mayoría portugueses, españoles e italianos, la mitad por diversos delitos contra la propiedad y falsificaciones de dinero, mientras la otra mitad era acusada de 
"crímenes políticos" y anarquismo. En esa lista, aparece Cordasco," que fue expulsado el 18 de agosto de 1894, con destino desconocido.

Un periódico anarquista de Buenos Aires, El Perseguido, publicó una brevenota sobreel "compañeroValentín Cordasco", con lainformación sobre el posible itinerario: después de ser preso en San Pablo, el 29 de junio, y de pasar 52 días incomunicado, habría sido embarcado hacia Europa. Principal órgano de prensa libertaria de la ciudad, El Perseguido era dirigido por el anarquista español Baldomero Salvans, víctima junto a Cordasco de la represión del gobierno de Floriano Peixoto. Mientras Cordasco era detenido con un grupo de italianos en San Pablo, Salvans terminó preso en Río de Janeiro, acusado de integrar una "asociación de individuos extranjeros", la mayoría españoles, que eran dedicados a la propaganda anarquista entre los obreros de una fábrica de tejidos del barrio de Gávea.

En agosto de 1893, todos ellos fueron expulsados de Brasil (algunos hacia España, otros al Río de la Plata) y el cónsul español se mantuvo al tanto de los procedimientos, intercediendo entre la acción policial y su gobierno, que estaba en plena guerra contra el anarquismo por la ola de atentados de esos años. De hecho, la información no era desacertada. Uno de los más estrepitosos de estos ataques, el atentado en la Gran Vía de Barcelona, ocurriría pocos días después de estas expulsiones en Río de Janeiro, protagonizado por el tipógrafo catalán Paulino Pallás, quien regresaba a Europa tras un paso por Argentina y Brasil. Preso por la policía y ejecutado por un pelotón de fusilamiento, su nombre seguiría resonando en Europa tras el famoso atentado en el Liceo de Barcelona de noviembre de 1893, porque el anarquista que lo cometió, juró hacerlo para vengar la trágica muerte de Pallás. Restaban pocas dudas para los policías y los cónsules: América del Sur había entrado al denso mapa de conexiones atlánticas del anarquismo.

Al igual que Cordasco, Baldomero Salvans retornaría a Brasil años después de su primera expulsión, tras una estadía en la Argentina. Nunca saldrían de la mira policial. Es significativo notar que ambos fueron acusados de tentativas de atentado con bombas de dinamita: Cordasco de organizar un ataque al presidente brasileño y Salvans de 
haber lanzado bombas en una fábrica de tejidos en España. Denuncias incomprobables, pero que funcionaban para recalcar que la policía no estaba frente a simples difusores de ideas, sino ante militantes de la "propaganda por el hecho", dispuestos a matar. Esas informaciones - posiblemente inventadas por la policía - eran fundamentales para enfrentar las resistencias que, ante las deportaciones sumarias de extranjeros, surgían del mundo jurídico y político.

Las expulsiones de extranjeros durante el gobierno de Floriano Peixoto se sustentaron en dos decretos presidenciales que le daban marco institucional a una práctica administrativa ya existente. El primero, promulgado el 13 de octubre de 1893, regulaba el ingreso de extranjeros al territorio nacional y su expulsión durante el estado de sitio. El espectro de sujetos susceptibles de deportación era amplio (mendigos, vagabundos, delincuentes de todo tipo) y se hacía énfasis en los "crímenes contra la libertad de trabajo", en los agitadores obreros que incitaran "actos de violencia contra diversas clases sociales". La expulsión se haría sin ningún proceso judicial de por medio, por una simple orden escrita del ministro de Justicia y Asuntos Interiores. Ante los cuestionamientos que fueron recibidos, un segundo decreto - revocatorio del anterior - fue publicado el 15 de diciembre del mismo año, aunque era ambiguo al refirmar la primacía de la defensa de la soberanía nacional y, de hecho, las expulsiones continuaron como atestigua el propio caso de Cordasco. Retrospectivamente, el jurista Geminiano da Franca veía en este decreto un "estado de sitio permanente" y una "dictadura hacia el extranjero", que suscitó "críticas ásperas y protestas vehementes contra esa entronización del arbitrio".

Este abogado, que había pasado por diversos cargos en la policía carioca, incluyendo la jefatura, hasta llegar a ser juez del Supremo Tribunal Federal, era una de las tantas voces que se levantaron contra la práctica de la expulsión de extranjeros que fue empleada por los distintos gobiernos, durante el primer período republicano en Brasil. Aunque se denunciaba la inconstitucional del decreto (que pasaba por alto los derechos constitucionales de los extranjeros), el eje de la embestida era, según las palabras del propio Geminiano da Franca, 
el "poder absoluto, sin oposición", los "caprichos del ejecutivo" que avanzaban sobre los otros poderes del estado. Por eso, el redactor de la nota sobre la deportación de Cordasco en El Perseguido, de Buenos Aires, escribía que esa ola de expulsiones de extranjeros "sucedían en el Brasil, donde se abolió el imperio por una república". Hace A apenas cuatro años de la proclamación de la república en 1889, y todo esto era percibido en la región como un retroceso, como un lugar de promesas incumplidas.

La ciudad de Buenos Aires, a la que fue a parar Baldomero Salvans y, más tarde, Valentino Cordasco, no estaba al margen de estas agitaciones. Tampoco las expulsiones sumarias de anarquistas le eran desconocidas. A fines de noviembre de 1893, poco después de la expulsión de Salvans de Brasil, la prensa porteña informaba que, "en cumplimiento de severas órdenes superiores", un grupo de cuarenta anarquistas había sido detenido cuando se encontraba reunido en una cantina de la calle Callao. Según investigaciones policiales, en la reunión se tramaban huelgas entre escritores de incendiarios artículos en los periódicos ácratas. Treinta y cuatro de los detenidos fueron puestos en libertad al día siguiente, mientras el resto fue conducido al Departamento de Policía.

Contemporáneo a los atentados anarquistas en Barcelona y París, el periplo de estos anarquistas convivía en los diarios porteños con el temor a esa mundializada "sed rabiosa de destrucción". Un cronista de La Prensa se acercó al Departamento de Policía cuando los anarquistas - los italianos, los españoles y los franceses - pasaron por la Oficina de Identificación, donde se le tomaron retratos y mediciones antropométricas. Al entrevistar alguno de los que fueron detenidos, el periodista los increpó sobre los atentados en Europa. Uno de ellos respondió que no ponían bombas y el otro acotó que eran, como casi todos los obreros del país, trabajadores extranjeros, que los verdaderos conspiradores eran los gobiernos. Pocos días después, todos, a excepción de uno, que prometió no seguir profesando ideas libertarias, fueron deportados a Uruguay.

La prensa libertaria rioplatense levantó su voz para denunciar la ola represiva. El Perseguido publicó una agria columna, con un relato 
sobre la creciente intolerancia de los gobiernos sudamericanos, que ya se aproximaban a los peores de Europa en materia de combate al anarquismo. Sin atentados de por medio, ordenaban prisiones arbitrarias y obligaban a salir del país, bajo amenaza de ser transportados al inhóspito y gélido Cabo de Hornos. Por su parte, los periódicos ácratas de Montevideo informaron de la llegada de los deportados de Buenos Aires. Uno de ellos acusaba a la prensa comercial de ignorancia y mala fe, cuando pedía que se detuviera y encarcelara a los ocho anarquistas "que ningún delito habían cometido y fueron expulsados de Argentina debido al estado de sitio, por la sola emisión del pensamiento".

Estos periódicos denunciaban un fenómeno que puede corroborarse con otras fuentes documentales: la emergencia de una red sudamericana de circulación de informaciones entre autoridades estatales de Argentina, Brasil y Uruguay que coordinaban acciones para vigilar a los anarquistas. De hecho, a comienzos de 1894, el jefe de la policía carioca recibió una carta del ministro de Relaciones Exteriores con una advertencia: temía que la policía de Montevideo decidiera expulsar a los ocho deportados de Buenos Aires y que en la travesía atlántica intentaran bajar en algún puerto brasileño. Dentro del mismo circuito, la policía de Buenos Aires envió a la de Río de Janeiro las fichas y las fotografías de estos desterrados, que a su vez fueron remitidas a las autoridades portuarias con el propósito de impedir su desembarco.

Esta dimensión de intercambios entre autoridades policiales y consulares de distintas ciudades era fundamental. Algunos años después de su primera deportación en 1894, el italiano Valentino Cordasco reaparece en otra lista de ácratas en Brasil. Esta vez, se trataba de una "relación de los anarquistas existentes" en Río de Janeiro que el jefe de la policía envió a Olinto de Magalhães, ministro de Relaciones Exteriores entre 1898 y 1902, en sucesivas cartas con carácter confidencial. Mucho menos lacónica que la lista de los que fueron expulsados de 1895, en este caso se resumían los prontuarios de cada anarquista vigilado por la policía carioca. En total, sumaban cuarenta pequeñas biografías, de las cuales treinta pertenecían a 
italianos como Cordasco. No era una lista de extranjeros indeseables, como queda claro por la inclusión del brasileño Antonio José Duarte Junior, trabajador negro, registrado como un "socio" de Baldomero Salvans. La previa aparición de muchos de estos nombres-incluyendo al propio Salvans - en las listas de mediados de la década de 1890, sugiere líneas de continuidad en la vigilancia policial de anarquistas que circulaban por las ciudades del atlántico sudamericano. Primera en esta nueva lista de 1901, la biografía policial de Cordasco, de prosa áspera, brindaba algunas pistas sobre sus pasos posteriores a la expulsión de 1894:

Este individuo es el distribuidor del diario Protesta Humana. Vive en la calle Luis de Camões número 72. Ese diario es un órgano anarquista. Valentino se viste correctamente y usa siempre un anillo de brillante en uno de los dedos de la mano derecha. Fue deportado del estado de San Pablo en 1893, cuando era propietario de un almacén. Fue preso en esta capital el $1^{\circ}$ de mayo de 1900 . Tiene retrato en la policía de San Pablo como anarquista. No tiene aquí ningún empleo.

En efecto, el diario La Protesta Humana, que - según la policía carioca - Cordasco distribuía en Brasil, era uno de los órganos más importantes de la prensa anarquista rioplatense y se convertiría, pocos años más tarde, en uno de los más gravitantes del mundo atlántico. Además, desde su primer número del 13 de junio de 1897, hizo de la circulación internacional uno de sus rasgos distintivos. Inicialmente, muy cercano a la realidad europea, con el tiempo se vinculó de lleno con la problemática regional del anarquismo, alcanzando en su distribución a ciudades como Montevideo, San Pablo, Río de Janeiro, Lima, Santiago de Chile y Asunción. La dimensión transfronteriza de La Protesta Humana no se agotó en la difusión de noticias, sino que además operó como articulador de diferentes iniciativas libertarias en América del Sur. Toda una exitosa estrategia de intercambios que abarcaba cables de Montevideo y Río de Janeiro, la traducción de 
notas provenientes de periódicos paulistas como A Lanterna y, más adelante, La Battaglia, la publicación de correspondencias y notas de opinión hicieron de La Protesta Humana un espacio de coordinación y vinculación transnacional del propio movimiento anarquista.

La policía carioca identificaba a Valentino Cordasco como un nodo de esa red. Cuando el jefe policial estaba terminando estas listas de ácratas para el ministro de Relaciones Exteriores decidió incluir a Cordasco una segunda vez. Sin repetir el resumen biográfico, se limitaba a agregar que, días después de la primera inclusión en la lista, el italiano había viajado a Petrópolis, regresando a Río de Janeiro poco después. Algo quedaba claro: la policía brasileña no le perdía el rastro, ni a Cordasco, ni a un centenar de anarquistas que - al igual que él - circulaban con frecuencia entre los principales puertos atlánticos de América del Sur.

Más allá de sus trayectorias singulares, todos esos casos compartían algunos rasgos. Por un lado, eran sujetos que recorrían las mismas rutas y frecuentaban las mismas redes que los trabajadores inmigrantes (la abrumadora mayoría, como revelan las listas, eran italianos y españoles). Por otro lado, enfrentaban la persecución de las autoridades de sus países de origen, que encabezaron, en la década de 1890, una severa represión internacional del anarquismo. Los efectos de esa vasta red alcanzaron a las repúblicas sudamericanas, como muestran una gran cantidad de documentos preservados en archivos policiales y diplomáticos. De hecho, en la carpeta del Itamaraty que contiene el inventario de anarquistas vigilados, otra misiva del jefe de policía al ministro de Relaciones Exteriores revela que la propia confección de las listas se debió a un pedido de autoridades de Alemania. En reunión con el canciller brasileño, los alemanes le habrían expresado la preocupación por "muchos anarquistas dirigidos al estado de Río Grande do Sul”, que desde allí "se diseminaron por el territorio nacional de Brasil para luego, eludiendo la vigilancia de la policía, regresar a Europa, a fin de llevar a cabo sus planos tenebrosos". En efecto, todas las páginas de la lista de anarquistas que eran vigilados por la policía carioca, llevaban una anotación al margen que decía "copiado al ministro alemán". 
El caso de Cordasco, se permite vislumbrar, a escala individual, el doble circuito de conexiones atlánticas, a la vez anarquista y policial. La imputación de "jefe de los anarquistas de América del Sur", formulada por el policía testigo en el proceso de expulsión de 1908, era una figuración que aludía a su papel de mediador entre periódicos libertarios de Brasil y el Río de la Plata. No es casual que muchos de los anarquistas que fueron incluidos en las listas participaran de esos emprendimientos periodísticos, que ocupaban un lugar central en las redes internacionales del anarquismo. La contracara de ese fenómeno, entonces, eran los circuitos de cooperación policial y consular, que muchas veces involucraban altas autoridades estatales en la búsqueda de contener la notable diseminación del anarquismo.

La persecución que padeció en Brasil desde los años 1890 se nutrió de esas tramas de intercambios, que envolvían a las policías de Río de Janeiro, San Pablo, Montevideo y Buenos Aires. A mediados de 1908, durante los meses de su segunda expulsión, el director de la Oficina de Identificación de la policía carioca envió una comunicación a la jefatura, informando que "según datos recibidos del servicio de investigaciones de Buenos Aires, Valentino Cordasco no registra antecedentes judiciales en aquella institución", aunque la policía porteña sabía de su existencia y lo había detenido, en febrero de 1905, cuando hacia propaganda de la resonante huelga general de ese año. La respuesta de Buenos Aires, al negar la existencia de antecedentes delictivos y reafirmar la condición de militante anarquista, iba a contramano del argumento usado por la policía de Río de Janeiro para solicitar al gobierno su expulsión.

"Este individuo es un peligrosísimo ladrón anarquista", escribía una autoridad del Cuerpo de Agentes de Seguridad Pública que era encargadao de seguirle los pasos: "dice ser vendedor de frutas, pero es solo para aparentar un medio de vida serio". Según esta versión, Cordasco había hecho una fortuna gracias a "transacciones ilícitas" que incluían robos, contrabando, juego clandestino, circulación de dinero falso y "propaganda del partido anarquista". Al igual que en la expulsión de 1894, estos artificios incriminatorios de la policía no pasaron sin cuestionamientos. Luego de ser preso por la policía 
carioca en mayo de 1908, recién llegado de Montevideo, Cordasco fue liberado mientras se tramitaba su proceso de expulsión. Entonces, se presentó en la sala de redacción del diario O Paiz, muñido de documentos de comprobaban su vida honesta y dispuesto a denunciar que su persecución se debía a "informaciones falsas que fueron enviadas a la policía, por espíritu de torpe venganza”.

Algunos diarios de Río de Janeiro, en franca oposición a la jefatura de policía, se hicieron eco de la denuncia. En el Correio da Manhã se leía que la prisión de Cordasco no había sido otra cosa, sino "uno de los muchos abusos que fueron practicados por inspiración de Arthur Andrade", entonces jefe del Cuerpo de Agentes de Seguridad Pública. El título de la nota - "Tempestad en un vaso de agua" - sintetizaba la diatriba periodística contra Andrade, acusado de "no tener noción alguna de lo que era un anarquista" y de haber elegido a cualquier "pobre diablo" para fraguar un éxito policial ante el supuesto "peligroso agitador de masas". Víctima del "inepto Andrade" y de su subordinado, el "zaparrastroso agente Guerra" (en alusión a Francisco Guerra, quien - como vimos - fue "testigo" en el proceso de expulsión), Cordasco había sufrido toda suerte de vejámenes y una detención de semanas en el "inmundo calabozo" del Departamento Central de Policía. En su tentativa por defenestrar a los agentes de seguridad pública y victimizar a Cordasco, sin embargo, el cronista terminaba negando no solo cualquier vínculo del italiano con el mundo del delito, sino también con el anarquismo.

Idéntica operación repetía un periodista de la Gazeta de Notícias en una crónica titulada "Un anarquista de mentira". Cordasco - escribía - "no pasaba de un pequeño propietario que hacía viajes entre Montevideo y Río de Janeiro". A fines de 1902 se había naturalizado ciudadano de Uruguay, país en el que tenía propiedades y cuentas bancarias. Quedaba claro que Cordasco había mostrado a la prensa carioca títulos de propiedad y talonarios del banco. En vez de bombas, ironizaba el cronista, el italiano traía esos papeles en el bolsillo. Al igual que en los diarios O Paiz y Correio da Manhã, aquí se sugería la invención de un inexistente anarquista peligroso: 
No hubo alma, del millón de buenas almas que habitan esta risueña ciudad, que no temblara de miedo. ¡Dios de los cielos, un anarquista! Y en seguida, el nombre apareció en el noticiario como si fuera escrito con letras de fuego y de sangre: Valentino Cordasco.

La visita a la sala de redacción de O Paiz y la versión difundida, en simultáneo, por el Correio da Manhã y la Gazeta de Notícias dejan entrever que Cordasco participó de la construcción de esta versión que lo presentaba como un cándido burgués viajero, con "paseos frecuentes" entre el Río de la Plata y Brasil, borrando así, de un plumazo, su pasado anarquista. Esa estrategia puede haber sido un consejo del abogado que presentó un habeas corpus, lo sacó del calabozo policial y, probablemente, evitó la deportación: Evaristo de Moraes. En ese momento, este personaje ya tenía una conocida actuación como defensor de derechos de militantes obreros y sindicatos, en particular de los trabajadores vinculados al mundo portuario (los estibadores, los foguistas y los cargadores de carbón). La asistencia jurídica a las asociaciones sindicales del puerto lo había convertido en un acérrimo crítico del accionar policial en un contexto marcado por fuertes movilizaciones y huelgas.

Según consta en el proceso de expulsión, el 14 de mayo de 1908 Evaristo de Moraes presentó un habeas corpus ante un juzgado federal, pidiendo la inmediata liberación de Valentino Cordasco, en ese entonces preso en la Casa de Detención por orden de la jefatura de policía y a disposición del Ministerio de Justicia para ser expulsado de Brasil. Esa medida extraordinaria, escribía Moraes en la petición, era absurda porque no se trataba "como pretende la policía, de un anarquista o un ladrón, sin haber respondido a cualquier proceso [criminal]". Sería extraño que el abogado brasileño desconociera la militancia anarquista de Cordasco, pero eligió el camino de ocultarla para evitar su expulsión. En este punto, la historia de Cordasco se desvanece, sin nuevas apariciones en la documentación policial y diplomática que permitan seguir esa trayectoria repleta de desplazamientos atlánticos, algunos forzados por deportaciones y otros, la gran mayoría, por decisión propia. Tampoco parece ser 
objeto de nuevas crónicas en la prensa.

\section{Leia-se:}

El 9 de mayo de 1908, el Delegado Auxiliar de la policía de Río de Janeiro tomaba declaración testimonial por un nuevo proceso de expulsión. Casi exactamente un año atrás, el presidente de la república Afonso Pena había sancionado la ley de expulsión de extranjeros indeseables, más conocida como Ley Adolfo Gordo. Según los registros oficiales, en ese primer ciclo anual se había decretado la expulsión de más de un centenar de extranjeros, aunque muchos se quedaron en Brasil gracias a pedidos de habeas corpus. La mayoría eran acusados de reincidencia en diferentes delitos contra la propiedad, vagabundaje, estafas y proxenetismo. Las listas publicadas en los informes del Ministerio de Justicia no revelan el motivo de la expulsión, pero es posible reconstruir esas acusaciones revisando los expedientes que se encuentran en el Archivo Nacional. Esa reconstrucción debe tener en cuenta las discordancias entre ambos registros: algunos nombres de las listas no constan en los legajos de expulsión y viceversa. Tal era el caso del italiano que enfrentó ese día el interrogatorio del Delegado Auxiliar. No figuraba en las listas oficiales, pero el sucinto proceso de expulsión brinda algunas pistas para comprender esa ausencia.

Indagado sobre sus datos de identidad, respondió llamarse Valentino Cordasco, haber nacido en la provincia de Avellino 52 años atrás, ser soltero, sastre de oficio y alfabetizado. La firma que rubricaba con su nombre la declaración, pese al trazo trémulo, parece confirmar que sabía leer y escribir. El mismo día y en la misma oficina policial, el Delegado Auxiliar escuchó a los testigos. Anotados como "empleados públicos" eran, como ocurría con la mayor parte de las expulsiones de extranjeros, agentes policiales que se limitaban a corroborar la versión acusatoria de la institución. Uno de ellos, Francisco Guerra, declaró que conocía al acusado desde 1899, que era "ladrón, vagabundo, pasador de billetes falsos y que se jactaba de ser el "jefe de los anarquistas de América del Sur". La imputación mezclaba, en un mismo relato, que el italiano "recibía diarios de diversas 
naciones de Europa”, dedicándose a la "propaganda de la anarquía”, con informaciones sobre la posesión de una supuesta fortuna en Uruguay, "adquirida por medio de robos practicados en esta capital [Río de Janeiro] y en los países vecinos”. El segundo testigo repetía la misma versión, apenas agregando que Cordasco solía circular dinero falso en espacios de juego clandestino.

Esa versión de los hechos había sido construida por la investigación policial y reafirmada por los cronistas de los diarios de circulación masiva. Conscientes de la atracción que suscitaban los anarquistas entre sus lectores desde los atentados del fin de siglo, celebraban con ironía la entrada de Río de Janeiro al concierto de ciudades que debían luchar contra este fenómeno tan moderno. En esa tónica, el caso Cordasco fue presentado a los lectores del diario O Século como uno de esos "hechos sensacionales que sugestionan al alma popular". A la capital brasileña "civilizada" por las recientes reformas urbanas del intendente Francisco Pereira Passos, solo le faltaban "anarquistas que pusieran en desasosiego a la población”. Se contaba, entonces, la historia del "tenaz, intransigente y fanático Valentino Cordasco". Llegado desde el Río de la Plata el 26 de abril de 1908 a bordo del vapor Umbria, no era - se explicaba - ningún desconocido para la policía carioca. En 1900, había sido preso en Río de Janeiro por una tentativa de atentado con dinamita al entonces presidente Campos Sales, en medio de las celebraciones por el cuarto centenario del descubrimiento de Brasil. Según este relato, en su poder fue encontrada una carta sobre planes de asesinato del presidente de los Estados Unidos de América, William McKinley, que terminó muriendo en un atentado anarquista al año siguiente.

Cuando la policía carioca supo que Cordasco pisaría de nuevo Brasil, puso al frente de la investigación al jefe del Cuerpo de Agentes de Seguridad Pública, Arthur Andrade. Esta autoridad aseguró haber recibido de la policía uruguaya la noticia de supuestas transacciones con moneda falsa como motivo de este nuevo desplazamiento. Con la propaganda libertaria como foco, explicaba el cronista, Cordasco había "viajado casi todo el universo" y actuaba en sus viajes como "agente de diarios anarquistas" de Buenos Aires, Nueva York y 
Madrid, además de dirigir un periódico libertario en el Uruguay, que llevaría el título de La Mosca. Un día después de la primera crónica, el repórter de O Século, siempre bien comunicado con la policía, corregía la información anterior. Esta detención de mayo de 1908 no era la segunda, sino la tercera en Brasil. Seis años antes del episodio de 1900, en julio de 1894, fue detenido en la ciudad de San Pablo en compañía de otros anarquistas italianos y expulsado del país. Esa detención - concluía - era el resultado de una "lista ofrecida a la policía por un cónsul italiano al que le gustaba entregarse al espionaje". Presos durante la vigencia del estado de sitio decretado por el presidente Floriano Peixoto, muchos de ellos fueron expulsados a la Argentina.

El archivo policial de Río de Janeiro brinda algunas pistas para cotejar esta versión: un informe reservado que el ministro de Justicia envió al jefe de policía en agosto de 1894 reproduce el decreto presidencial autorizando la deportación de Cordasco. En la misma carpeta de este fondo documental puede encontrarse otro informe reservado, datado al comienzo de la presidencia de Prudente de Morais, en el que se solicita una lista de los extranjeros expulsados de Brasil durante la administración previa. En la respuesta queda clara la magnitud de esa ola de expulsiones sumarias, muy anteriores a la ley de 1907: entre junio de 1893 y noviembre de 1894 se expulsaron alrededor de setenta extranjeros, la mayoría portugueses, españoles e italianos, la mitad por diversos delitos contra la propiedad y falsificaciones de dinero, mientras la otra mitad era acusada de "crímenes políticos" y anarquismo. En esa lista aparece Cordasco, expulsado el 18 de agosto de 1894, con destino desconocido.

Un periódico anarquista de Buenos Aires, El Perseguido, publicó una breve nota sobre el "compañero Valentín Cordasco" con información sobre el posible itinerario: después de ser preso en San Pablo el 29 de junio y de pasar 52 días incomunicado, habría sido embarcado hacia Europa. Principal órgano de prensa libertaria de la ciudad, El Perseguido era dirigido por el anarquista español Baldomero Salvans, víctima junto a Cordasco de la represión del gobierno de Floriano Peixoto. Mientras Cordasco era detenido con un grupo de italianos 
en San Pablo, Salvans terminó preso en Río de Janeiro, acusado de integrar una "asociación de individuos extranjeros", la mayoría españoles, dedicados a la propaganda anarquista entre los obreros de una fábrica de tejidos del barrio de Gávea.

En agosto de 1893, todos ellos fueron expulsados de Brasil (algunos hacia España, otros al Río de la Plata) y el cónsul español se mantuvo al tanto de los procedimientos, intercediendo entre la acción policial y su gobierno, que estaba en plena guerra contra el anarquismo por la ola de atentados de esos años. De hecho, la información no era desacertada. Uno de los más estrepitosos de estos ataques, el atentado en la Gran Vía de Barcelona, ocurriría pocos días después de estas expulsiones en Río de Janeiro, protagonizado por el tipógrafo catalán Paulino Pallás, quien regresaba a Europa tras un paso por Argentina y Brasil. Preso por la policía y ejecutado por un pelotón de fusilamiento, su nombre seguiría resonando en Europa tras el famoso atentado en el Liceo de Barcelona de noviembre de 1893, porque el anarquista que lo cometió juró hacerlo para vengar la trágica muerte de Pallás. Restaban pocas dudas para los policías y los cónsules: América del Sur había entrado al denso mapa de conexiones atlánticas del anarquismo.

Al igual que Cordasco, Baldomero Salvans retornaría a Brasil años después de su primera expulsión, tras una estadía en la Argentina. Nunca saldrían de la mira policial. Es significativo notar que ambos fueron acusados de tentativas de atentado con bombas de dinamita: Cordasco de organizar un ataque al presidente brasileño y Salvans de haber lanzado bombas en una fábrica de tejidos en España. Denuncias incomprobables, pero que funcionaban para recalcar que la policía no estaba frente a simples difusores de ideas, sino ante militantes de la "propaganda por el hecho", dispuestos a matar. Esas informaciones - posiblemente inventadas por la policía - eran fundamentales para enfrentar las resistencias que, ante las deportaciones sumarias de extranjeros, surgían del mundo jurídico y político.

Las expulsiones de extranjeros durante el gobierno de Floriano Peixoto se sustentaron en dos decretos presidenciales que le daban marco institucional a una práctica administrativa ya existente. $\mathrm{El}$ 
primero, promulgado el 13 de octubre de 1893, regulaba el ingreso de extranjeros al territorio nacional y su expulsión durante el estado de sitio. El espectro de sujetos susceptibles de deportación era amplio (mendigos, vagabundos, delincuentes de todo tipo) y se hacía énfasis en los "crímenes contra la libertad de trabajo", en los agitadores obreros que incitaran "actos de violencia contra diversas clases sociales”. La expulsión se haría sin ningún proceso judicial de por medio, por una simple orden escrita del ministro de Justicia y Asuntos Interiores. Ante los cuestionamientos recibidos, un segundo decreto - revocatorio del anterior - fue publicado el 15 de diciembre del mismo año, aunque era ambiguo al refirmar la primacía de la defensa de la soberanía nacional $y$, de hecho, las expulsiones continuaron como atestigua el propio caso de Cordasco. Retrospectivamente, el jurista Geminiano da Franca veía en este decreto un "estado de sitio permanente" y una "dictadura hacia el extranjero", que suscitó "críticas ásperas y protestas vehementes contra esa entronización del arbitrio”.

Este abogado, que había pasado por diversos cargos en la policía carioca, incluyendo la jefatura, hasta llegar a ser juez del Supremo Tribunal Federal, era una de las tantas voces que se levantaron contra la práctica de la expulsión de extranjeros empleada por los distintos gobiernos durante el primer período republicano en Brasil. Aunque se denunciaba la inconstitucional del decreto (que pasaba por alto los derechos constitucionales de los extranjeros), el eje de la embestida era, según las palabras del propio Geminiano da Franca, el "poder absoluto, sin oposición", los "caprichos del ejecutivo" que avanzaban sobre los otros poderes del estado. Por eso el redactor de la nota sobre la deportación de Cordasco en El Perseguido de Buenos Aires escribía que esa ola de expulsiones de extranjeros "sucedían en el Brasil, donde se abolió el imperio por una república”. A apenas cuatro años de la proclamación de la república en 1889 , todo esto era percibido en la región como un retroceso, como un lugar de promesas incumplidas.

La ciudad de Buenos Aires a la que fue a parar Baldomero Salvans y, más tarde, Valentino Cordasco no estaba al margen de estas agitaciones. Tampoco las expulsiones sumarias de anarquistas le 
eran desconocidas. A fines de noviembre de 1893, poco después de la expulsión de Salvans de Brasil, la prensa porteña informaba que, "en cumplimiento de severas órdenes superiores", un grupo de cuarenta anarquistas había sido detenido cuando se encontraba reunido en una cantina de la calle Callao. Según investigaciones policiales, en la reunión se tramaban huelgas entre escritores de incendiarios artículos en los periódicos ácratas. Treinta y cuatro de los detenidos fueron puestos en libertad al día siguiente, mientras el resto fue conducido al Departamento de Policía.

Contemporáneo a los atentados anarquistas en Barcelona y París, el periplo de estos anarquistas convivía en los diarios porteños con el temor a esa mundializada "sed rabiosa de destrucción". Un cronista de La Prensa se acercó al Departamento de Policía cuando los anarquistas - italianos, españoles y franceses - pasaron por la Oficina de Identificación, donde se le tomaron retratos y mediciones antropométricas. Al entrevistar alguno de los detenidos, el periodista los increpó sobre los atentados en Europa. Uno de ellos respondió que no ponían bombas y otro acotó que eran, como casi todos los obreros del país, trabajadores extranjeros, que los verdaderos conspiradores eran los gobiernos. Pocos días después, todos, a excepción de uno que prometió no seguir profesando ideas libertarias, fueron deportados a Uruguay.

La prensa libertaria rioplatense levantó su voz para denunciar la ola represiva. El Perseguido publicó una agria columna con un relato sobre la creciente intolerancia de los gobiernos sudamericanos, que ya se aproximaban a los peores de Europa en materia de combate al anarquismo. Sin atentados de por medio, ordenaban prisiones arbitrarias y obligaban a salir del país, bajo amenaza de ser transportados al inhóspito y gélido Cabo de Hornos. Por su parte, periódicos ácratas de Montevideo informaron de la llegada de los deportados de Buenos Aires. Uno de ellos acusaba a la prensa comercial de ignorancia y mala fe, cuando pedía que se detuviera y encarcelara a los ocho anarquistas "que ningún delito habían cometido y fueron expulsados de Argentina debido al estado de sitio, por la sola emisión del pensamiento". 
Estos periódicos denunciaban un fenómeno que puede corroborarse con otras fuentes documentales: la emergencia de una red sudamericana de circulación de informaciones entre autoridades estatales de Argentina, Brasil y Uruguay que coordinaban acciones para vigilar a los anarquistas. De hecho, a comienzos de 1894, el jefe de la policía carioca recibió una carta del ministro de Relaciones Exteriores con una advertencia: temía que la policía de Montevideo decidiera expulsar a los ocho deportados de Buenos Aires y que en la travesía atlántica intentaran bajar en algún puerto brasileño. Dentro del mismo circuito, la policía de Buenos Aires envió a la de Río de Janeiro las fichas y las fotografías de estos desterrados, que a su vez fueron remitidas a las autoridades portuarias con el propósito de impedir su desembarco.

Esta dimensión de intercambios entre autoridades policiales y consulares de distintas ciudades era fundamental. Algunos años después de su primera deportación en 1894, el italiano Valentino Cordasco reaparece en otra lista de ácratas en Brasil. Esta vez, se trataba de una "relación de los anarquistas existentes" en Río de Janeiro que el jefe de la policía envió a Olinto de Magalhães, ministro de Relaciones Exteriores entre 1898 y 1902, en sucesivas cartas con carácter confidencial. Mucho menos lacónica que la lista de expulsados de 1895, en este caso se resumían los prontuarios de cada anarquista vigilado por la policía carioca. En total, sumaban cuarenta pequeñas biografías, de las cuales treinta pertenecían a italianos como Cordasco. No era una lista de extranjeros indeseables, como queda claro por la inclusión del brasileño Antonio José Duarte Junior, trabajador negro, registrado como un "socio" de Baldomero Salvans. La previa aparición de muchos de estos nombres - incluyendo al propio Salvans - en las listas de mediados de la década de 1890, sugiere líneas de continuidad en la vigilancia policial de anarquistas que circulaban por las ciudades del atlántico sudamericano. Primera en esta nueva lista de 1901, la biografía policial de Cordasco, de prosa áspera, brindaba algunas pistas sobre sus pasos posteriores a la expulsión de 1894: 
Este individuo es el distribuidor del diario Protesta Humana. Vive en la calle Luis de Camões número 72. Ese diario es un órgano anarquista. Valentino se viste correctamente y usa siempre un anillo de brillante en uno de los dedos de la mano derecha. Fue deportado del estado de San Pablo en 1893, cuando era propietario de un almacén. Fue preso en esta capital el $1^{\circ}$ de mayo de 1900 . Tiene retrato en la policía de San Pablo como anarquista. No tiene aquí ningún empleo.

En efecto, el diario La Protesta Humana que - según la policía carioca - Cordasco distribuía en Brasil, era uno de los órganos más importantes de la prensa anarquista rioplatense y se convertiría, pocos años más tarde, en uno de los más gravitantes del mundo atlántico. Además, desde su primer número del 13 de junio de 1897, hizo de la circulación internacional uno de sus rasgos distintivos. Inicialmente muy cercano a la realidad europea, con el tiempo se vinculó de lleno con la problemática regional del anarquismo alcanzando en su distribución a ciudades como Montevideo, San Pablo, Río de Janeiro, Lima, Santiago de Chile y Asunción. La dimensión transfronteriza de La Protesta Humana no se agotó en la difusión de noticias, sino que además operó como articulador de diferentes iniciativas libertarias en América del Sur. Toda una exitosa estrategia de intercambios que abarcaba cables de Montevideo y Río de Janeiro, la traducción de notas provenientes de periódicos paulistas como A Lanterna y, más adelante, La Battaglia, la publicación de correspondencias y notas de opinión hicieron de La Protesta Humana un espacio de coordinación y vinculación transnacional del propio movimiento anarquista.

La policía carioca identificaba a Valentino Cordasco como un nodo de esa red. Cuando el jefe policial estaba terminando estas listas de ácratas para el ministro de Relaciones Exteriores decidió incluir a Cordasco una segunda vez. Sin repetir el resumen biográfico, se limitaba a agregar que, días después de la primera inclusión en la lista, el italiano había viajado a Petrópolis, regresando a Río de Janeiro poco después. Algo quedaba claro: la policía brasileña no le perdía el rastro, ni a Cordasco, ni a un centenar de anarquistas que - al igual que él - circulaban con frecuencia entre los principales 
puertos atlánticos de América del Sur.

Más allá de sus trayectorias singulares, todos esos casos compartían algunos rasgos. Por un lado, eran sujetos que recorrían las mismas rutas y frecuentaban las mismas redes que los trabajadores inmigrantes (la abrumadora mayoría, como revelan las listas, eran italianos y españoles). Por otro lado, enfrentaban la persecución de las autoridades de sus países de origen, que encabezaron, en la década de 1890, una severa represión internacional del anarquismo. Los efectos de esa vasta red alcanzaron a las repúblicas sudamericanas, como muestran una gran cantidad de documentos preservados en archivos policiales y diplomáticos. De hecho, en la carpeta del Itamaraty que contiene el inventario de anarquistas vigilados, otra misiva del jefe de policía al ministro de Relaciones Exteriores revela que la propia confección de las listas se debió a un pedido de autoridades de Alemania. En reunión con el canciller brasileño, los alemanes le habrían expresado la preocupación por "muchos anarquistas dirigidos al estado de Río Grande do Sul", que desde allí "se diseminaron por el territorio nacional de Brasil para luego, eludiendo la vigilancia de la policía, regresar a Europa, a fin de llevar a cabo sus planos tenebrosos". En efecto, todas las páginas de la lista de anarquistas vigilados por la policía carioca llevaban una anotación al margen que decía "copiado al ministro alemán".

El caso de Cordasco permite vislumbrar, a escala individual, el doble circuito de conexiones atlánticas, a la vez anarquista y policial. La imputación de "jefe de los anarquistas de América del Sur", formulada por el policía testigo en el proceso de expulsión de 1908, era una figuración que aludía a su papel de mediador entre periódicos libertarios de Brasil y el Río de la Plata. No es casual que muchos de los anarquistas incluidos en las listas participaran de esos emprendimientos periodísticos, que ocupaban un lugar central en las redes internacionales del anarquismo. La contracara de ese fenómeno, entonces, eran los circuitos de cooperación policial y consular, que muchas veces involucraban altas autoridades estatales en la búsqueda de contener la notable diseminación del anarquismo.

La persecución que padeció en Brasil desde los años 1890 se nutrió de 
esas tramas de intercambios, que envolvían a las policías de Río de Janeiro, San Pablo, Montevideo y Buenos Aires. A mediados de 1908, durante los meses de su segunda expulsión, el director de la Oficina de Identificación de la policía carioca envió una comunicación a la jefatura, informando que "según datos recibidos del servicio de investigaciones de Buenos Aires, Valentino Cordasco no registra antecedentes judiciales en aquella institución", aunque la policía porteña sabía de su existencia y lo había detenido, en febrero de 1905, cuando hacia propaganda de la resonante huelga general de ese año. La respuesta de Buenos Aires, al negar la existencia de antecedentes delictivos y reafirmar la condición de militante anarquista, iba a contramano del argumento usado por la policía de Río de Janeiro para solicitar al gobierno su expulsión.

"Este individuo es un peligrosísimo ladrón anarquista", escribía una autoridad del Cuerpo de Agentes de Seguridad Pública encargado de seguirle los pasos: "dice ser vendedor de frutas, pero es solo para aparentar un medio de vida serio”. Según esta versión, Cordasco había hecho una fortuna gracias a "transacciones ilícitas" que incluían robos, contrabando, juego clandestino, circulación de dinero falso y "propaganda del partido anarquista". Al igual que en la expulsión de 1894, estos artificios incriminatorios de la policía no pasaron sin cuestionamientos. Luego de ser preso por la policía carioca en mayo de 1908, recién llegado de Montevideo, Cordasco fue liberado mientras se tramitaba su proceso de expulsión. Entonces se presentó en la sala de redacción del diario O Paiz muñido de documentos de comprobaban su vida honesta y dispuesto a denunciar que su persecución se debía a "informaciones falsas enviadas a la policía por espíritu de torpe venganza”.

Algunos diarios de Río de Janeiro, en franca oposición a la jefatura de policía, se hicieron eco de la denuncia. En el Correio da Manhã se leía que la prisión de Cordasco no había sido otra cosa sino "uno de los muchos abusos practicados por inspiración de Arthur Andrade", entonces jefe del Cuerpo de Agentes de Seguridad Pública. El título de la nota - "Tempestad en un vaso de agua" - sintetizaba la diatriba periodística contra Andrade, acusado de "no tener noción alguna de 
lo que era un anarquista" y haber elegido a cualquier "pobre diablo" para fraguar un éxito policial ante el supuesto "peligroso agitador de masas". Víctima del "inepto Andrade" y de su subordinado, el "zaparrastroso agente Guerra" (en alusión a Francisco Guerra, quien - como vimos - fue "testigo" en el proceso de expulsión), Cordasco había sufrido toda suerte de vejámenes y una detención de semanas en el "inmundo calabozo" del Departamento Central de Policía. En su tentativa por defenestrar a los agentes de seguridad pública y victimizar a Cordasco, sin embargo, el cronista terminaba negando no solo cualquier vínculo del italiano con el mundo del delito, sino también con el anarquismo.

Idéntica operación repetía un periodista de la Gazeta de Notícias en una crónica titulada "Un anarquista de mentira". Cordasco - escribía - "no pasaba de un pequeño propietario que hacía viajes entre Montevideo y Río de Janeiro". A fines de 1902 se había naturalizado ciudadano de Uruguay, país en el que tenía propiedades y cuentas bancarias. Quedaba claro que Cordasco había mostrado a la prensa carioca títulos de propiedad y talonarios del banco. En vez de bombas, ironizaba el cronista, el italiano traía esos papeles en el bolsillo. Al igual que en los diarios O Paiz y Correio da Manhã, aquí se sugería la invención de un inexistente anarquista peligroso:

No hubo alma, del millón de buenas almas que habitan esta risueña ciudad, que no temblara de miedo. ¡Dios de los cielos, un anarquista! $Y$ en seguida el nombre apareció en el noticiario como si fuera escrito con letras de fuego y de sangre: Valentino Cordasco.

La visita a la sala de redacción de O Paiz y la versión difundida, en simultáneo, por el Correio da Manhã y la Gazeta de Notícias dejan entrever que Cordasco participó de la construcción de esta versión que lo presentaba como un cándido burgués viajero, con "paseos frecuentes" entre el Río de la Plata y Brasil, borrando así de un plumazo su pasado anarquista. Esa estrategia puede haber sido un consejo 
del abogado que presentó un habeas corpus, lo sacó del calabozo policial y probablemente evitó la deportación: Evaristo de Moraes. En ese momento, este personaje ya tenía una conocida actuación como defensor de derechos de militantes obreros y sindicatos, en particular de los trabajadores vinculados al mundo portuario (estibadores, foguistas y cargadores de carbón). La asistencia jurídica a las asociaciones sindicales del puerto lo había convertido en un acérrimo crítico del accionar policial en un contexto marcado por fuertes movilizaciones y huelgas.

Según consta en el proceso de expulsión, el 14 de mayo de 1908 Evaristo de Moraes presentó un habeas corpus ante un juzgado federal, pidiendo la inmediata liberación de Valentino Cordasco, en ese entonces preso en la Casa de Detención por orden de la jefatura de policía y a disposición del Ministerio de Justicia para ser expulsado de Brasil. Esa medida extraordinaria, escribía Moraes en la petición, era absurda porque no se trataba "como pretende la policía, de un anarquista o un ladrón, sin haber respondido a cualquier proceso [criminal]". Sería extraño que el abogado brasileño desconociera la militancia anarquista de Cordasco, pero eligió el camino de ocultarla para evitar su expulsión. En este punto, la historia de Cordasco se desvanece, sin nuevas apariciones en la documentación policial y diplomática que permitan seguir esa trayectoria repleta de desplazamientos atlánticos, algunos forzados por deportaciones y otros, la gran mayoría, por decisión propia. Tampoco parece ser objeto de nuevas crónicas en la prensa.

Na página 333/357, onde se lia:

En enero de 1904, Víctor Valle, un ex-anarquista devenido agente de investigaciones y que era conocido en el medio obrero por el pseudónimo "el manchao"[...]

\section{Leia-se:}

En enero de 1904, Víctor Valle, un ex-anarquista devenido agente de investigaciones y conocido en el medio obrero por el pseudónimo "el 
manchao"[...]

Na página 334/357, onde se lia:

Hasta tal punto era así que el informe policial remarcaba la soltura y la seguridad con la que Carballo [...]

\section{Leia-se:}

Hasta tal punto era así que el informe policial remarcaba la soltura y seguridad con la que Carballo [...]

Nas páginas 334-335/357, onde se lia:

Conocida popularmente, con el nombre de Ley de Residencia, fue aprobada en noviembre de 1902, durante la primera huelga general en la Argentina, que también paralizó las actividades portuarias. Esta ley había nacido en un contexto de estado de sitio, bajo la sombra de la excepcionalidad y la inconstitucionalidad, reñida con el preámbulo de la Constitución que garantizaba derechos iguales a nativos y a extranjeros.

\section{Leia-se:}

Conocida popularmente con el nombre de Ley de Residencia, fue aprobada en noviembre de 1902 durante la primera huelga general en la Argentina, que también paralizó las actividades portuarias. Esta ley había nacido en un contexto de estado de sitio, bajo la sombra de la excepcionalidad y la inconstitucionalidad, reñida con el preámbulo de la Constitución que garantizaba derechos iguales a nativos y extranjeros.

Na página 335/357, onde se lia:

Era en ese gremio que el "alma y el eje de todo movimiento subversivo", tenían, además, una llamativa capacidad de confundir a la autoridad. Intuyendo que podía ser detenido, se adelantaba [...] 


\section{Leia-se:}

Era en ese gremio el "alma y eje de todo movimiento subversivo" y tenía, además, una llamativa capacidad de confundir a la autoridad. Intuyendo que podía ser detenido se adelantaba [...]

\section{Na página 336/357, onde se lia:}

Según Rossi, la centralidad de Carballo dentro del sindicato portuario se debía a su capacidad de articular relaciones y de lograr que otros le prestaran colaboración. En el pedido de expulsión de 1904, por ejemplo, figuran los nombres de Juan Alegre, alias "El chino alegre", uruguayo y el "anarquista convencido" [...]

\section{E onde se lia:}

[...]como novedad, incluiría la presencia de trabajadores del puerto de Montevideo, en igualdad de condiciones, con sus pares de la Argentina. Pese a la expectativa inicial, el congreso fue un fracaso. Promediando las sesiones, varios delegados se fueron, entre ellos Constante Carballo, que había asistido [...]

\section{Leia-se:}

Según Rossi, la centralidad de Carballo dentro del sindicato portuario se debía a su capacidad de articular relaciones y lograr que otros le prestaran colaboración. En el pedido de expulsión de 1904, por ejemplo, figuran los nombres de Juan Alegre, alias "El chino alegre", uruguayo y "anarquista convencido" [...]

\section{E Leia-se:}

[...]como novedad, incluiría la presencia de trabajadores del puerto de Montevideo en igualdad de condiciones con sus pares de la Argentina. Pese a la expectativa inicial, el congreso fue un fracaso. Promediando las sesiones varios delegados se fueron, entre ellos Constante Carballo que había asistido [...] 
Na página 337/357, onde se lia:

La falta de acuerdo, en este congreso, de los estibadores [...]

\section{Leia-se:}

La falta de acuerdo en este congreso de los estibadores [...]

\section{E onde se lia:}

[...]además de las diferentes asociaciones gremiales de estibadores, a carreros, a marineros y a foguistas, a la redacción del diario La Protesta.

\section{Leia-se:}

[...]además de las diferentes asociaciones gremiales de estibadores, carreros, marineros y foguistas, la redacción del diario La Protesta.

Na página 338/357, onde se lia:

[...]de los portuarios argentinos viajaron a Brasil para participar de actividades que fueron organizadas por la Sociedad Unión de los Operarios Estibadores de Río de Janeiro.

\section{Leia-se:}

[...]de los portuarios argentinos viajaron a Brasil para participar de actividades organizadas por la Sociedad Unión de los Operarios Estibadores de Río de Janeiro. 
Na página 341/357, onde se lia:

Justamente Vázquez y Corney serían detenidos y serían expulsados junto $[\ldots]$

\section{Leia-se:}

Justamente Vázquez y Corney serían detenidos y expulsados junto $[\ldots]$

\section{E onde se lia:}

[...]civiles y militares, que eran comandados por la [...]

\section{Leia-se:}

[...]civiles y militares, comandados por la [...]

Na página 343/357, onde se lia:

[...] anclado en la rada exterior del puerto, se encontraban los demás que habían sido expulsados, [...]

\section{Leia-se:}

[...]anclado en la rada exterior del puerto, se encontraban los demás expulsados, [...]

Nas páginas 343-344/357, onde se lia:

[...]se ha hecho sentir, principalmente, en el seno de los estibadores" y era visto por las autoridades como "la bestia negra de la policía de La Boca, agentes marítimos y exportadores de frutos". Esta imagen, alusiva a su presencia descollante en el barrio portuario por excelencia de Buenos Aires, reproducía irónicamente un recurso simbólico usual entre periodistas, criminólogos y autoridades policiales: la asociación del anarquismo con representaciones, a menudo racializadas, de lo monstruoso y de lo bestial. 


\section{Leia-se:}

se ha hecho sentir principalmente en el seno de los estibadores" y era visto por las autoridades como "la bestia negra de la policía de La Boca, agentes marítimos y exportadores de frutos". Esta imagen, alusiva a su presencia descollante en el barrio portuario por excelencia de Buenos Aires, reproducía irónicamente un recurso simbólico usual entre periodistas, criminólogos y autoridades policiales: la asociación del anarquismo con representaciones, a menudo racializadas, de lo monstruoso y lo bestial.

Na página 344/357, onde se lia:

Los relatos de Alberto Ghiraldo y de Francisco Corney permiten comprender el lugar de Montevideo en este espacio de conexiones atlánticas. Ya desde la aprobación de la Ley de Residencia a fines de 1902, la policía porteña observaba con preocupación cómo los anarquistas que habían sido expulsados de Buenos Aires, en vez de $[\ldots]$

\section{Leia-se:}

Los relatos de Alberto Ghiraldo y Francisco Corney permiten comprender el lugar de Montevideo en este espacio de conexiones atlánticas. Ya desde la aprobación de la Ley de Residencia a fines de 1902, la policía porteña observaba con preocupación cómo los anarquistas expulsados de Buenos Aires, en vez de [...]

Na página 345/357, onde se lia:

[...] evitó el descenso de dos anarquistas que habían sido expulsados de Buenos Aires [...]

\section{Leia-se:}

[...] evitó el descenso de dos anarquistas expulsados de Buenos Aires $[\ldots]$ 
Na página 347/357, onde se lia:

[...] (en sí mismo un testimonio de la continuidad de la vigilancia de los anarquistas que habían sido expulsados en el lugar de destierro) $[\ldots]$

\section{Leia-se:}

[...] (en sí mismo un testimonio de la continuidad de la vigilancia de los anarquistas expulsados en el lugar de destierro) [...]

Na página 348/357, onde se lia:

[...]expulsión de un militante, que ya era habituado a este procedimiento policial, se convirtió en un caso de testigo de un cambio de actitud [...]

\section{Leia-se:}

[...] expulsión de un militante ya habituado a este procedimiento policial se convirtió en un caso testigo de un cambio de actitud [...]

\section{E onde se lia:}

[...]la política uruguaya frente a los anarquistas que habían sido expulsados de Buenos Aires, se debía [...]

\section{Leia-se:}

[...]la política uruguaya frente a los anarquistas expulsados de Buenos Aires se debía [...]

Na página 349/357, onde se lia:

En esos días, Williman fue blanco predilecto de las diatribas anarquistas. En coincidencia con la percepción del cónsul argentino, un artículo incendiario que había sido publicado en Buenos Aires, daba cuenta del nuevo escenario: "hasta ayer, muchos creyeron que en el Uruguay existía una relativa libertad, y ahora, deben 
desengañarse".

\section{Leia-se:}

En esos días Williman fue blanco predilecto de las diatribas anarquistas. En coincidencia con la percepción del cónsul argentino, un artículo incendiario publicado en Buenos Aires daba cuenta del nuevo escenario: : "hasta ayer muchos creyeron que en el Uruguay existía una relativa libertad y ahora deben desengañarse".

Na página 350/357, onde se lia:

La carta, que fue enviada desde el Departamento [...]

\section{Leia-se:}

La carta, enviada desde el Departamento [...]

Na página 351/357, onde se lia:

[...]Suárez había sido detenido y había sido deportado desde Buenos Aires con destino a Barcelona.

\section{Leia-se:}

[...]Suárez había sido detenido y deportado desde Buenos Aires con destino a Barcelona.

Na página 352/357, onde se lia:

[...]policías paulistas al grito de "você não pode desembarcar", expresión que la carta, que había sido, redactada en castellano, [...]

\section{Leia-se:}

[...]policías paulistas al grito de "você não pode desembarcar", expresión que la carta, redactada en castellano, [...]

Na página 353/357, onde se lia: 
[...]la disputa por los efectos de los decretos y de las leyes de expulsión $[\ldots]$

\section{Leia-se:}

[...]la disputa por los efectos de los decretos y leyes de expulsión [...]

Na página 354/357, onde se lia:

Es muy probable que se hayan conocido, aunque los documentos que fueron consultados no permitan corroborarlo. El propagandista inquieto, que atravesó la década de 1890, portando, a los ojos de la policía y de la prensa, las tan difundidas características del anarcodelincuente y el incansable militante gremial, que hacía pie en la organización obrera y la huelga, eran - a pesar de sus marcadas diferencias - parte de un mismo espacio de circulaciones, del mundo atlántico de los agitadores móviles.

\section{Leia-se:}

Es muy probable que se hayan conocido, aunque los documentos consultados no permitan corroborarlo. El propagandista inquieto que atravesó la década de 1890 portando, a los ojos de la policía y de la prensa, las tan difundidas características del anarco-delincuente y el incansable militante gremial que hacía pie en la organización obrera y la huelga, eran - a pesar de sus marcadas diferencias - parte de un mismo espacio de circulaciones, del mundo atlántico de los agitadores móviles. 